Article

\title{
An Innovative Façade Element with Controlled Solar-Thermal Collector and Storage
}

\author{
Thomas Wüest* $*$, Lars O. Grobe $\mathbb{}^{\circledR}$ and Andreas Luible \\ Competence Centre Building Envelope, Institute of Civil Engineering, Lucerne University of Applied Sciences \\ and Arts, CH-6048 Horw, Switzerland; larsoliver.grobe@hslu.ch (L.O.G.); andreas.luible@hslu.ch (A.L.) \\ * Correspondence: thomas.wueest@hslu.ch; Tel.: +41-41-349-3842
}

Received: 5 June 2020; Accepted: 27 June 2020; Published: 30 June 2020

check for updates

\begin{abstract}
A novel façade element is presented that forms a symbiosis between an enhanced box-type window, a closed cavity façade, and a Trombe wall. This hybrid, transparent-opaque façade element features an absorbing water tank, that is installed behind a controlled shading device toward the cavity of a non-ventilated Double Skin Façade in the parapet section. To evaluate the potential impact on building performance, a transient simulation model is developed in Modelica and calibrated by comparison with measurements on a prototype. The effect of the absorbing thermal storage on heat transfers under solar radiation is analyzed in comparison to (i) conditions excluding solar radiation and (ii) an empty tank. An evaluation for four European cities demonstrates that the annual heating demand can be reduced by more than $4.2 \%$ and cooling demand by at least $6.6 \%$ compared to a façade without thermal storage. The effect is explained not only by the increased thermal mass, but also by the effective modulation of solar gains by the controlled absorbing storage. The dampening of heat flow fluctuations and the control of solar gains is a promising means to reduce the installed power of HVAC (heating/ventilating/air conditioning) installations.
\end{abstract}

Keywords: Trombe wall; closed cavity façade; building dynamic simulations; thermal storage; passive solar façade; real-world test system; Modelica

\section{Introduction}

\subsection{Closed Cavity Façades and Trombe Walls}

Building envelopes can play a key role in achieving targets for climate change mitigation and energy sustainability whilst enhancing the wellbeing of building tenants. Since the 1980s, Double-Skin Façades (DSFs) have been used in tall office and administration buildings. DSFs offer various advantages: high aesthetic value, good thermal/acoustic performance and the ability to protect shading devices from dirt and wind gusts. The ongoing development and improvements of the technology led to the emergence of new systems, e.g., the Closed-Cavity Façade (CCF). The CCF differs from the naturally ventilated DSF in that its cavity is fully sealed with a modest dry air flow [1]. Since DSFs are usually applied to buildings with highly glazed building envelopes, they potentially lead to overheating in summertime, when peak outside-air temperatures coincide with high solar gains, which is usually considered the main drawback of these façade types [2,3].

Another promising approach to reduce total energy consumption are passive solar façades. These do not involve any mechanical devices but rather leverage the dependence of insolation on orientation and employ the thermal mass of exterior walls, i.e., to store and redistribute heat. Typical examples for such passive solar façades, e.g., Trombe Walls (TWs) and solar chimneys, have a high potential for reducing the building heat load by up to $50 \%$ [4]. TWs, in particular, are an active field of building research addressing environmental and energy issues $[5,6]$. 
CCFs offer the same advantages as other DSFs, but require less maintenance. The lack of natural ventilation increases the risk of overheating within the cavity and, due to solar gains increasing with glazing areas, within the attached spaces. TWs have the potential to mitigate the high sensitivity of buildings to fluctuating solar gains. Usually made of solid elements without windows, they are typically limited to opaque façade areas. Further, the utilization of TWs as warm air heating systems reduces the heat storage and, combined with a poor insulation, causes high energy losses at nighttime. While the positive effects of CCFs and TWs are apparently complementary, the two technologies have not been combined in a unified façade system so far.

The effect of passive thermal mass on different positions in a naturally and mechanically ventilated DSF has been investigated by [7]. The authors state considerable reductions of energy load when thermal mass was integrated into a mechanically ventilated DSF. Replacing the shading with concrete mass achieved energy savings from $21 \%$ to $26 \%$ in summer, and $41 \%$ to $59 \%$ in winter compared to a conventional DSF with aluminum Venetian blinds. On the other hand, the effect disappears on natural ventilated DSFs. Similar results were presented by [8], where an opaque, mechanically ventilated DSF with thermal mass (PCM) was monitored. Energy savings of about $20 \%$ under summer conditions were achieved.

Another approach is the use of solar energy for electrical energy production. In [9], a semi-transparent DSF with integrated photovoltaic (PV) was investigated. The primary benefit is the reduction of electricity use within the attached room due to daylight use by semi-transparent PVs, which is about $50 \%$.

\subsection{Objectives}

The novel Solar Energy Balanced Façade (SEBF) shall combine the benefits of a modern, glazed CCF with the effects of an established passive solar façade system such as the TW on the thermal performance of a building. The integration of a TW element as a thermal storage within the CCF shall reduce overheating and provide a means to make controlled use of solar energy to reduce heat losses. Other than the ventilated DSFs evaluated in previous research $[8,10,11]$, the SEBF is not actively ventilated or used for active energy production, e.g., for hot water or room heating. An accurate transient heat flow model of the façade element shall be developed and validated by comparison against measurements on a test cell [12]. The effect of solar energy use and solar thermal storage are evaluated by annual simulations under the climatic conditions of four locations in Europe. Based on these, the effects of the integration of the thermal mass into the façade shall be analyzed:

- The impact of solar irradiation on heating and cooling in the test box,

- the impact of thermal mass on the energy balance of the test box,

- the impact of the integration of the thermal mass in the façade to modulate heat flows,

- the impacts on energy demand for heating and cooling in different European locations.

\section{Development and Assessment of the Solar Energy Balanced Façade}

\subsection{Concept and Design}

The SEBF integrates a parapet into a CCF to form a hybrid, opaque-transparent element-façade [13]. Similar to other CCFs, it shall achieve the thermal insulation and protection of the shading devices from the weather without the high cleaning efforts of conventional DSFs. The transparent zone admits daylight and provides a view to the outside $[14,15]$. The opaque parapet allows to configure the WWR (window to wall ratio) for energy performance [16]. The SEBF aims to reduce heating and cooling demands by the passive use and active control of solar gains within the façade layer.

The primary aim of the SEBF is to reduce heat losses from the building's interior through the façade. Due to the inward insulation, the thermal storage is effectively located within the CCF's cavity. It stores solar energy and releases it to the cavity with a delay. The insulation reduces passive gains in the room, which could cause overheating on sunny days even in winter. The stored heat is rather released to the outside through the cavity as soon as the sun sets and the exterior temperature decreases. 
With its interior insulation, the parapet achieves a U-value lower than the Triple Glazing Unit (TGU) forming the transparent zone above.

The secondary aim of the SEBF is to temporally balance heat gains and losses. The thermal storage causes a time shift in the response of the transparent and opaque zones of the SEBF. While changing solar irradiance is instantaneously reflected by energy flows through the transparent zone, the response of the opaque parapet is delayed by the integrated thermal storage. This effect dampens heat flows in both directions and potentially allows reducing the installed power or operation of HVAC (heating/ventilating/air conditioning) systems.

The SEBF actively manages solar gains by an innovative seasonal day and night control strategy of the integrated shading device. The shading of the opaque and transparent zones is controlled separately. Figure 1 illustrates exemplary states during daytime and at night in summer and winter.

In summer, the control aims to achieve night cooling and supports heat losses from the storage (b). During the day, the shading device decreases solar gains through the TGU and the absorption on the opaque zone from direct gains that would heat up the thermal mass (a). The thermal mass moderates the air temperature in the cavity.

During winter days, the shading device is retracted and exposes the opaque zone to incident irradiance (c). The absorbed solar energy is stored by the thermal mass and released during the night (d). This increases the air temperature in the cavity and decreases building energy losses by outward heat transmission through the SEBF.

The independent shading control of the transparent zone allows for the tuning of solar gains and daylight as desired and within a comfortable range. The functionality of the opaque zone is maintained even if manual overriding of the shading control for the transparent zone is allowed.

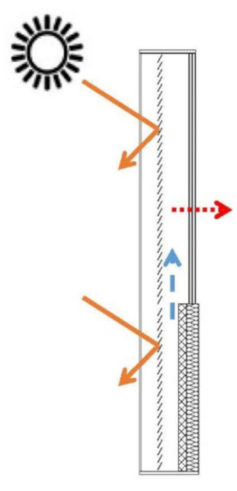

(a)

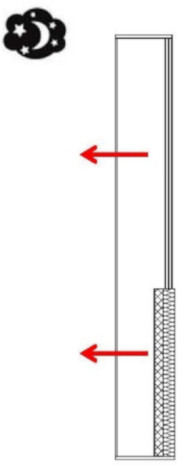

(b)

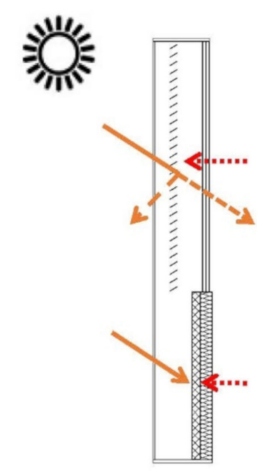

(c)

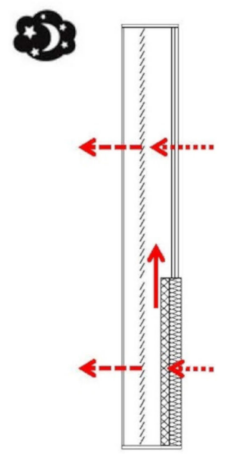

(d)

Figure 1. Energy management: Summer days (a) and nights (b), and winter days (c) and nights (d). Red $=$ heat flux, blue $=$ "cool flux", yellow = solar energy. Dashed lines = lower flux, dotted lines = greatly reduced flux.

\subsection{Prototype}

Preliminary studies with the Modelica-Dymola simulation software assessed the theoretical functionality of the SEBF [13] but also pointed out uncertainties that may affect its application. Therefore, a full-scale, functional prototype was set up to further investigate the SEBF and to improve and test its model.

\subsubsection{Setup of the Prototype}

The SEBF prototype is implemented as a "breathing", closed, non-ventilated DSF (in French, "façade respirante"). There is no conditioned air supply. Air in- and exfiltration by thermal expansion is allowed through a controlled aperture covered by a dust filter. The façade comprises two identical elements, that are installed side by side. As shown in Figure 2, each façade element consists of 
- $\quad$ an inner frame, horizontally divided in two areas that are covered by the insulated panel $\left(1.5 \mathrm{~m}^{2}\right)$ of the parapet and the TGU $\left(1.9 \mathrm{~m}^{2}\right)$ forming the transparent zone,

- the thermal storage, comprising an aluminum tank painted black and attached to the outside of the insulated panels,

- Venetian blinds in the cavity, split into two zones at the upper level of the parapet, and

- an external transom-mullion system frame holding the external single pane glazing.

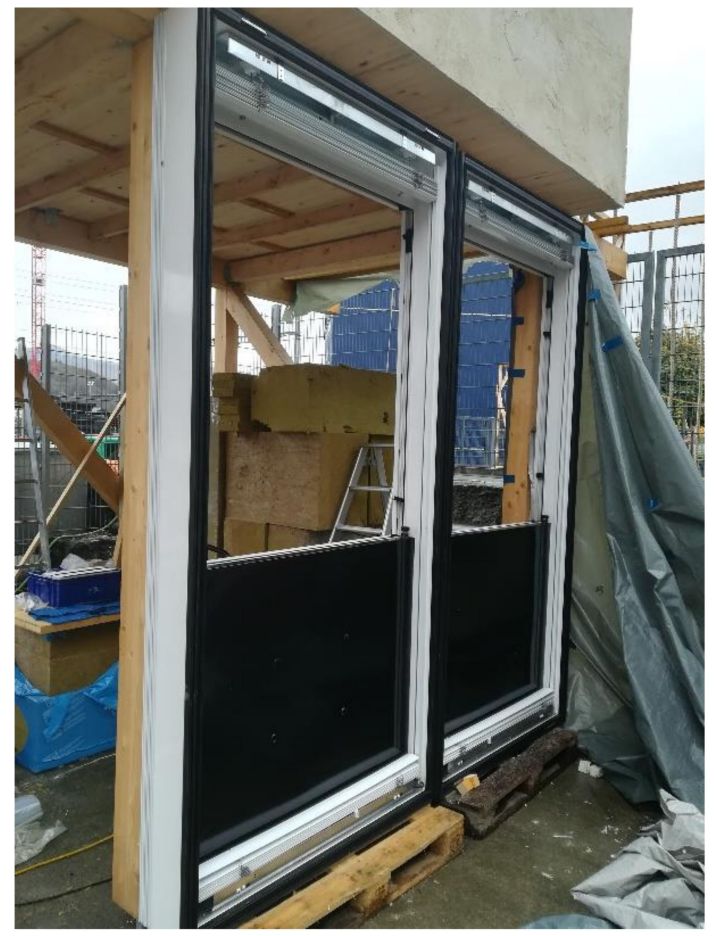

(a)

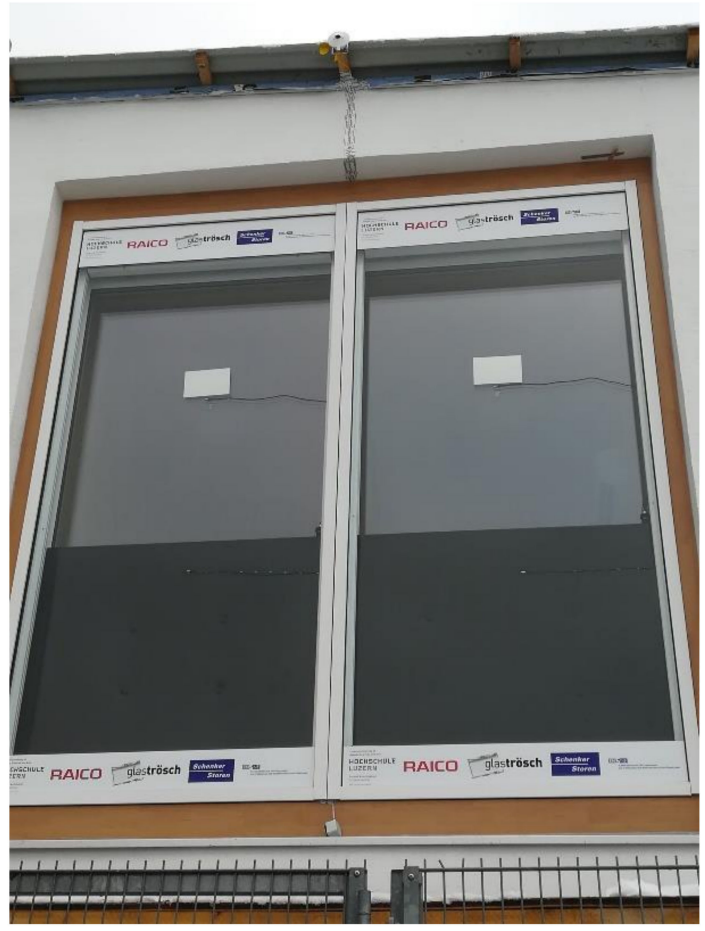

(b)

Figure 2. SEBF prototypes during assembly (a) and mounted (b).

The construction space in the façade limits the thickness of the tank to $50 \mathrm{~mm}$, with an inside width of $46 \mathrm{~mm}$. Important dimensions and material properties are reported in Table 1. Each element is equipped with thermal sensors on the interior surfaces, the external surface of the TGU, the core of the parapet's insulation, the core of the tank, and the external surface of the tank. For comparison, the two elements were configured differently with regard to their thermal storage:

- $S E B F_{w}$ : With subscript $\mathrm{w}$ standing for water, the tank of this element is filled with water gel. Water as storage material was chosen because of its outstanding thermal storage capacity. To prevent damages in case of leakage, the water is gelled with a plastic granulate. As a positive side effect, the gelled water prevents convection and decreases thermal conductivity from $0.6 \mathrm{Wm}^{-1} \mathrm{~K}^{-1}$ to $0.35 \mathrm{Wm}^{-1} \mathrm{~K}^{-1}$ (Table 1 ).

- $S E B F_{a}$ : With subscript a standing for air, this element is identical to $\mathrm{SEBF}_{\mathrm{w}}$, except for its tank being empty.

Together, the two elements form the south-facing wall of a test cell [12]. The cell comprises an $8.6 \mathrm{~m}^{2}$ conditioned space and a $6 \mathrm{~m}^{2}$ maintenance room. The cell's walls are highly insulated $\left(\mathrm{U}=0.08 \mathrm{Wm}^{-2} \mathrm{~K}^{-1}\right)$ and have no significant thermal mass, except for $40 \mathrm{~mm}$ wooden plates covering the inner side of the wall. Under steady conditions (external air temperature of $0{ }^{\circ} \mathrm{C}$, no solar irradiation), heat transfer through the SEBF causes $49 \%$ of the total heating demand. The low thermal mass of the room increases the operation of the HVAC unit and the impact of the SEBF's thermal mass.

The SEBF elements were equipped with digital thermal sensors (DS18B20 from Maxim Integrate, USA, on a one-wire bus). The manufacturer specifies an accuracy of $+/-0.5 \mathrm{~K}$. Sensor response 
was corrected for offset and slope [12]. Vertical solar irradiation was recorded by an ISO Second Class Pyranometer (Kipp \& Zonen SMP3-V). Internal and external air temperatures, prototype layer temperatures, vertical global solar irradiation, and shading state were monitored at intervals of one minute on single-board computers (Raspberry Pi, Raspberry Pi Foundation, UK).

The properties of gas layers (air and Argon in the TGU) were described by the temperature-dependent properties according to ISO 15099 [17]. The $\mathrm{T}^{4}$ correlation model for surface to surface thermal radiation was used. For forced external heat transfer, the ISO 15099 [17] models for windward and $\mathrm{T}^{4}$ thermal radiation correlation were chosen. The internal surface heat transfer was modeled according to EN 6946 [18].

Table 1. Properties of relevant components of the SEBF (data from standards and suppliers).

\begin{tabular}{cccccc}
\hline Material & $\begin{array}{c}\text { Thickness } \\
\mathbf{t}[\mathbf{m m}]\end{array}$ & $\begin{array}{c}\text { Conductivity } \\
\boldsymbol{\lambda}\left[\mathbf{W m}^{-\mathbf{2}} \mathbf{K}^{-\mathbf{1}}\right]\end{array}$ & $\begin{array}{c}\text { Density } \\
\boldsymbol{\rho}\left[\mathbf{k g m}^{-\mathbf{3}}\right]\end{array}$ & $\begin{array}{c}\text { Heat Capacity } \\
\mathbf{c}\left[\mathbf{J k g}^{-\mathbf{1}} \mathbf{K}^{-\mathbf{1}}\right]\end{array}$ & $\begin{array}{c}\text { Emissivity } \\
\boldsymbol{\varepsilon}[-]\end{array}$ \\
\hline External glass ply & 6 & 1 & 2700 & 750 & 0.837 \\
TGU plies & 4 & 1 & 2700 & 750 & $0.837 / 0.02^{1}$ \\
Shading (Aluminum) & 1 & 160 & 2700 & 900 & 0.9 \\
Tank (Aluminum) & 3 & 160 & 2700 & 900 & $0.9 / 0.1^{2}$ \\
Insulation & 70 & 0.04 & 30 & 1400 & - \\
Water & 40 & $0.35^{3}$ & $1001.3^{4}$ & 4180 & - \\
\hline
\end{tabular}

${ }^{1}$ Emissivity of LowE coatings are regarded with $\varepsilon=0.02$ on positions 2 and 5 of TGU. ${ }^{2}$ Emissivity of untreated aluminum is regarded with $\varepsilon=0.1$ according to EN 10077-2:2017 [19]. ${ }^{3}$ Upper value measured by Linseis THB-100.

${ }^{4}$ Multiplied with " $\mathrm{f}_{\text {water }}=0.98$ " to respect the density of the gel.

\subsubsection{Findings from the Setup of the Prototype}

Comparing a tank filled with water to an empty (air-filled) one allowed for the investigation of two border cases and revealed challenges in the application of water as a façade-integrated thermal storage. Gelling the water effectively prevented leakage but not evaporation from the tank. This phenomenon was revealed by an inspection of the tank during the tests in springtime and was stronger than expected. The improved sealing of the tank reduced the evaporation rate but could not entirely rule it out, as revealed by a later, second inspection. This research accounts for this effect by assuming a reduced water level of $80 \%$ of the tank's volume in the subsequently monitored summer period and a correction of water density in the model $\left(f_{\text {water }}=0.8\right)$.

Another potential issue when introducing water into façades is the risk of freezing. During the measurement period, a minimum external air temperature of $-5.1^{\circ} \mathrm{C}$ was measured (in the morning of 23 January 2019). At that time, the surface temperatures in the tanks of $\mathrm{SEBF}_{\mathrm{a}}$ and $\mathrm{SEBF}_{\mathrm{w}}$ fell to $-2.0^{\circ} \mathrm{C}$ and $+1.9^{\circ} \mathrm{C}$, respectively. While no damage due to freezing occurred during the study, the proximity of the measured temperature to the water's freezing point suggests that further investigation of freezing risk should be carried out for cold winter periods without solar irradiation.

\subsection{Heat Transfer Model}

An existing simulation model of the SEBF [13], that had been implemented in Modelica based on ISO 15099 [17], was tested and refined based on the monitored behavior of the prototype. Vertical irradiance, that was only monitored globally, in front of the prototypes, was interpreted by a simplified model attributing the measurement to direct and diffuse irradiance components. The original model had assumed independent heat flows for the transparent and opaque zones of the façade as a function of local weather data [20]. This simplification was overcome by a coupled model to account for the interaction between the cavities in front of the opaque and transparent zones. The model was validated by comparison to two periods of consistent measurement data:

(a) Winter: One week in December, 19-25 December 2018, and

(b) Summer: Two weeks in August, 8-27 August 2019 


\subsubsection{Prediction of Angular-Dependent Gains Based on Global Irradiance Measurements}

While optical glazing properties are usually determined by EN 410 [21] for irradiance normal to the surface, transmittance and reflection depend on the incident angle according to Fresnel's equations. This had to be taken into account in the calculation of solar gains through the transparent façade zone. It also affects the exposure of the thermal storage, which is placed behind a single glazing, for solar irradiance. Angular solar-optical properties of clear façade layers for any incident angle were calculated from their optical properties at normal incidence (provided by the manufacturers) with a normalized factor derived from Fresnel's equations for clear glass [22]. This directional correction factor is applied only to the direct component of solar irradiance. Diffuse radiance was assumed to be isotropic, and optical properties at normal incidence were applied.

To separate the measured global irradiance into its direct and diffuse components, a sensitivity study, based on standard meteorological data from [20] with given direct and diffuse solar irradiation was conducted. The outward surface temperatures of the TGU and storage tank were calculated from the original 1D model of the SEBF [13], and four different sky models parametrized by global irradiance were compared:

(i) direct and diffuse from meteorological data [20],

(ii) all global irradiance attributed to diffuse irradiance,

(iii) all global irradiance accounted for as direct, and

(iv) a split model, assuming that $95 \%$ of global irradiance exceeding $150 \mathrm{~W} / \mathrm{m}^{2}$ is direct.

As shown in Figure 3, models (ii and iii) relying only on global irradiance achieve significantly different accordance with the detailed direct and diffuse model (i). The assumption of entirely diffuse and direct irradiance (models ii and iii) overestimates and underestimates the surface temperature, respectively. The split model (iv) allows for a close replication of the surface temperature predicted by model (i).

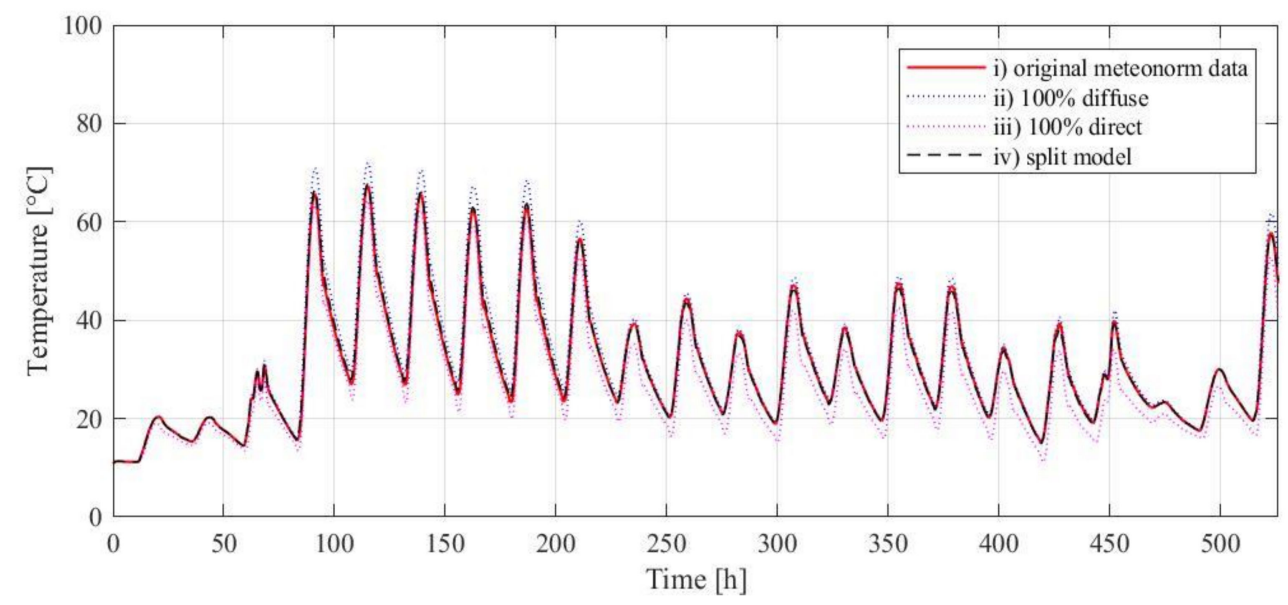

Figure 3. SEBF water tank surface temperature modeled with different attributions of global to direct and diffuse irradiance.

\subsubsection{Vertical Heat Flows Between Cavities of Transparent and Opaque Zones}

A comparison of the original model of the SEBF [13] with the measurements revealed that on sunny days (e.g., $t=40 \mathrm{~h}$ ) the surface temperatures of the tank were significantly overestimated (Figure 4), while the external TGU surface temperature was underestimated. The temperature descent of $\mathrm{SEBF}_{\mathrm{w}}$ was much slower than measured. Both deviations can be explained by an upward heat flow in the cavity from the parapet to the transparent façade zone. The flow is caused by rising warm air but was not accounted for by the original model. On cloudy days, simulated and measured temperatures differed marginally $(< \pm 1.5 \mathrm{~K})$. 


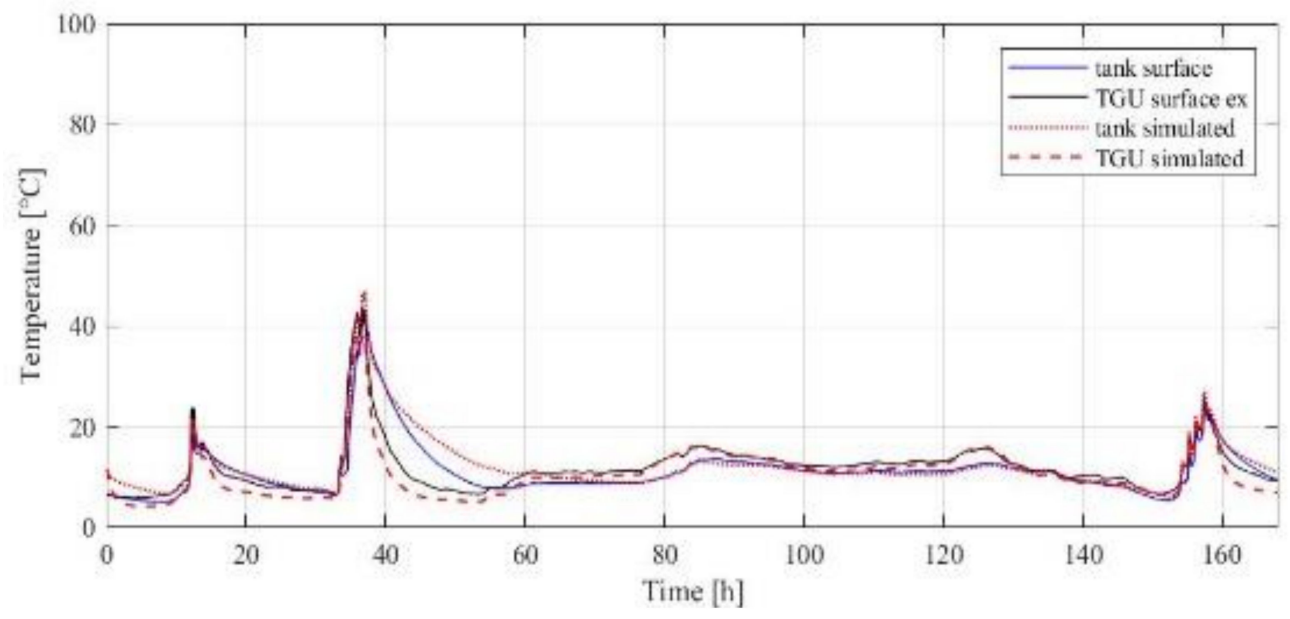

(a)

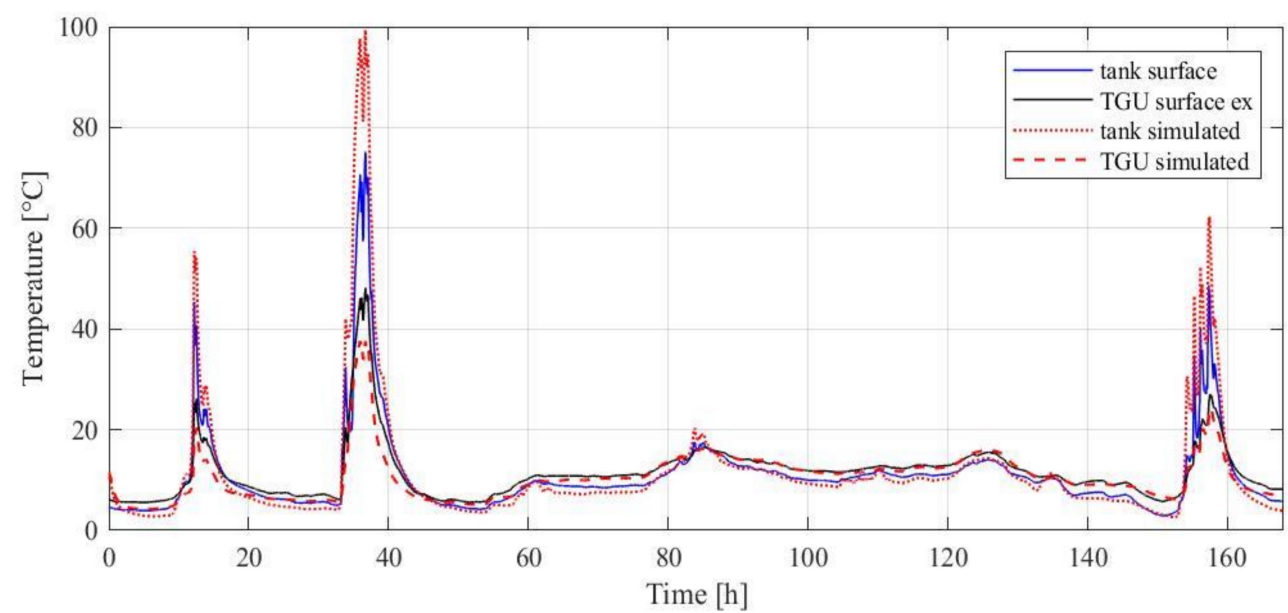

(b)

Figure 4. Predicted and measured temperatures of external tank and TGU surfaces with (a) $\mathrm{SEBF}_{\mathrm{W}}$ filled and (b) $\mathrm{SEBF}_{\mathrm{a}}$ in winter.

In summer, the shading devices are typically closed at daytime. In Figure 5, the overestimation of the external TGU surface temperature and the underestimation of the tank surface temperature are visible, especially for $\mathrm{SEBF}_{\mathrm{w}}$. The expected "cooling effect" of the thermal mass in the cavity causes a downdraught of warm air from the TGU toward the tank. This is not accounted for by the model and can explain the disagreement of the model with the measurement. 


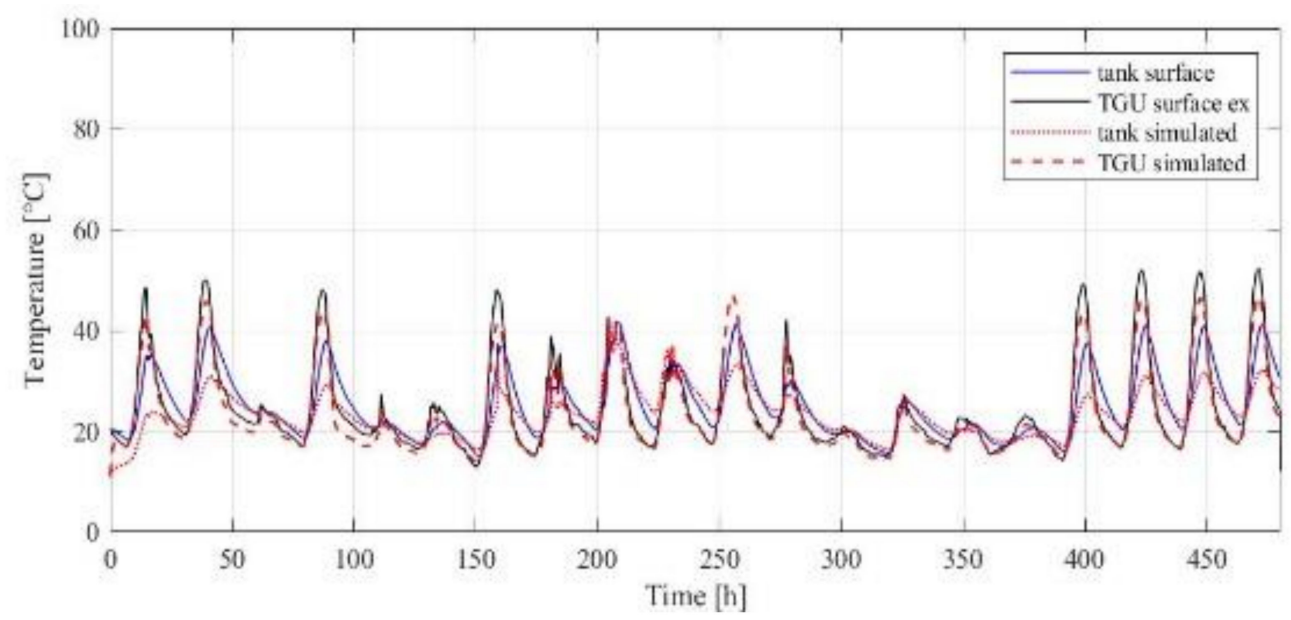

(a)

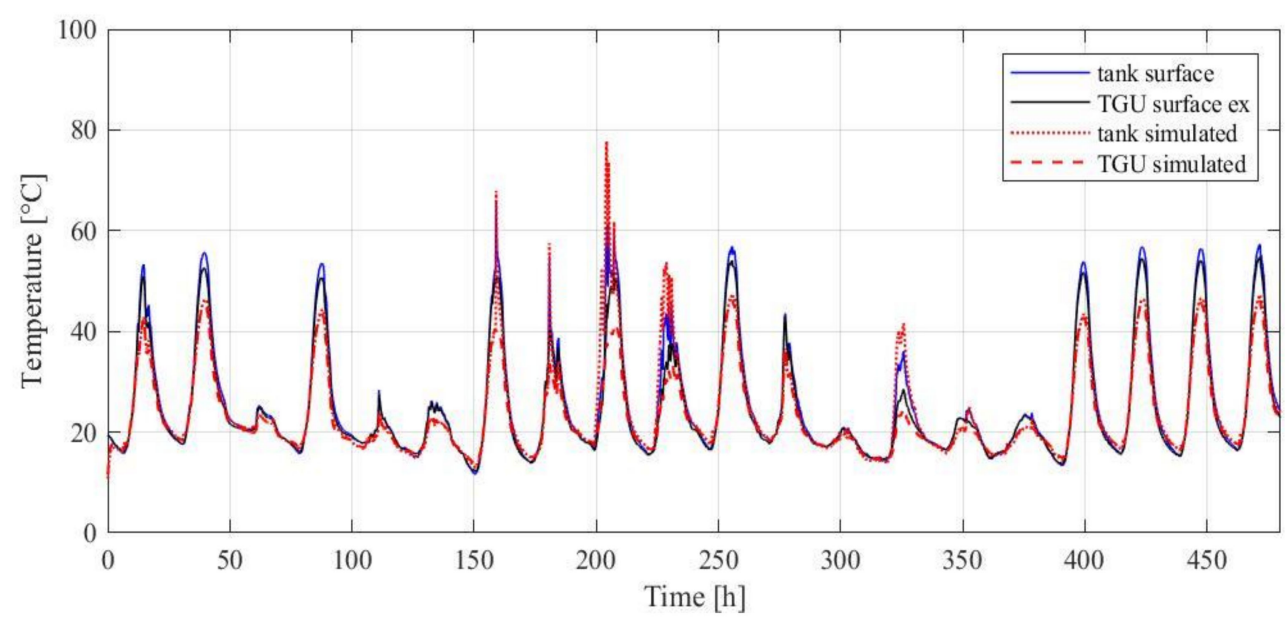

(b)

Figure 5. Predicted and measured temperatures of tank surface and external TGU surface for $\mathrm{SEBF}_{\mathrm{w}}$ (a) and $\mathrm{SEBF}_{\mathrm{a}}$ (b) elements during summer weeks (80\% water filling).

\subsubsection{Refined and Calibrated Simulation Model}

Based on the phenomena observed in the measured data, the original model was refined and calibrated. The focus lied on an accurate description of the effect for both types of elements and all seasons, and not on a situation and/or element-based fitting. Due to the complexity of coupling two vertical zones of the cavity in front of the TGU and the parapet, a direct gas node connection to a heat conduction element was not feasible. Instead, two heat flow elements were introduced in the model that couple heat flows through the TGU and those through the parapet. The coefficients were iteratively determined employing the Modelica-Dymola optimizer and by manual adjustments guided by least-square fitting.

The first introduced heat flow element connects the external surface of the TGU and that of the tank by a bidirectional heat conductor to distinguish upward and downward heat flows. Such flows are represented by connections in Modelica. The connection is always active. Fitting provided values for upward and downward heat flows of $6 \mathrm{WK}^{-1}$ and $3 \mathrm{WK}^{-1}$, respectively.

The second element connects the tank's surface to the upper external glazing. This conductor is only active if the lower shading is open and supports only upward heat flows. The upward heat flow from the tank to the upper external glazing is set to $2.5 \mathrm{WK}^{-1}$. 
Figures 6 and 7 show a comparison of the refined model results with the measurements shown in Figures 4 and 5. The improved model achieves a significantly better agreement. In Tables 2 and 3 , key statistics are summarized as temperature differenced $(\Delta \mathrm{T})$ and Root Mean Square Error (RMSE), beginning with the 24th hour of the simulation to eliminate disturbances of start conditions. Positive differences indicate that the simulation is overestimating the temperatures (by up to $22 \mathrm{~K}$ ). Those high deviations within a minute occur on sunny days with high short-time fluctuations of solar irradiation (day 2 and 7 in winter and day 7, 8, and 9 in summer). On other steady sunny days, the deviations are within +3 and $-4 \mathrm{~K}$, which is regarded as acceptable.

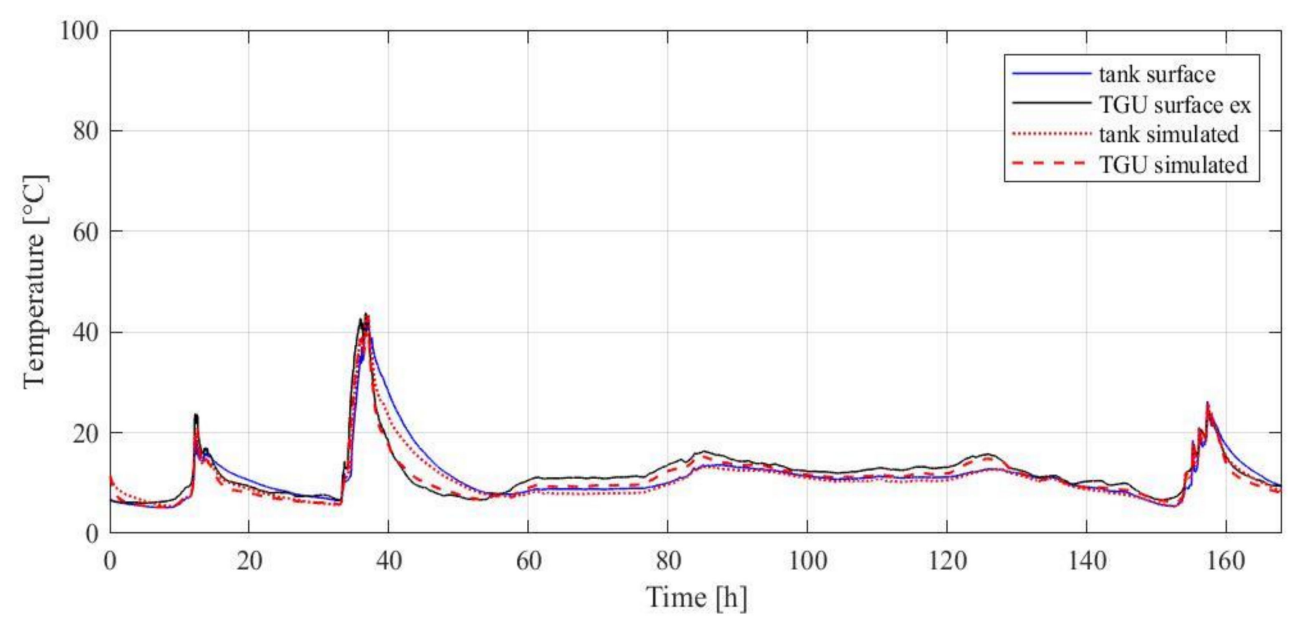

(a)

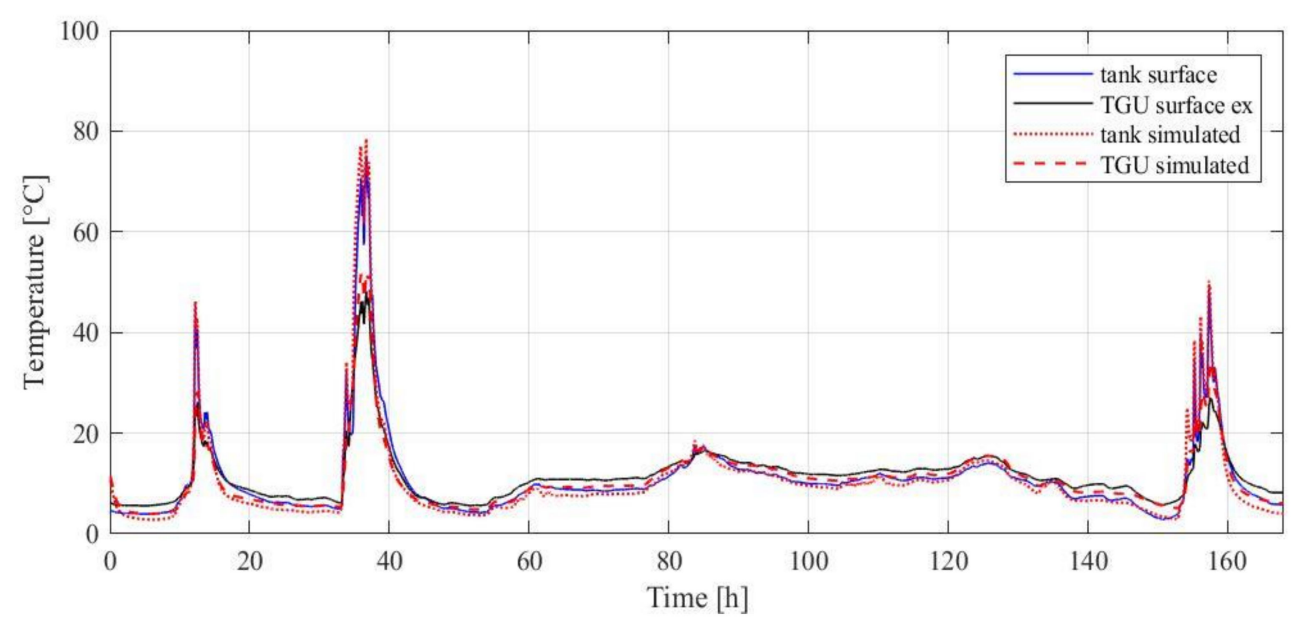

(b)

Figure 6. Predicted and measured temperatures as in Figure 4, but with refined and calibrated model. (a) $\mathrm{SEBF}_{\mathrm{w}}$ filled and (b) $\mathrm{SEBF}_{\mathrm{a}}$ in winter. 
Table 2. Statistics of the differences between simulated and measured temperatures $[\mathrm{K}]$ of the tank of $\mathrm{SEBF}_{\mathrm{a}}$ starting from the 24th hour of simulation at intervals of one minute.

\begin{tabular}{llcccccc}
\hline & $\begin{array}{c}\text { Tank } \\
\text { Surface }\end{array}$ & $\begin{array}{c}\text { Tank Core } \\
\text { (Air) }\end{array}$ & $\begin{array}{c}\text { Parapet } \\
\text { Insulation } \\
\text { Core }\end{array}$ & $\begin{array}{c}\text { Parapet } \\
\text { Inner } \\
\text { Surface }\end{array}$ & $\begin{array}{c}\text { TGU } \\
\text { External } \\
\text { Surface }\end{array}$ & $\begin{array}{c}\text { TGU } \\
\text { Internal } \\
\text { Surface }\end{array}$ \\
\hline \multirow{5}{*}{ Winter } & $\Delta$ T max. $[\mathrm{K}]$ & 18.22 & 21.73 & 3.81 & 2.00 & 7.31 & 2.89 \\
& $\Delta$ T min. $[\mathrm{K}]$ & -4.70 & -0.29 & 0.12 & -0.39 & -2.42 & -0.64 \\
& $\Delta$ T average $[\mathrm{K}]$ & -0.48 & 1.11 & 0.75 & 0.51 & -0.65 & -0.05 \\
& RMSE $[-]$ & 1.85 & 1.87 & 0.93 & 0.55 & 1.56 & 0.40 \\
\hline \multirow{5}{*}{ Summer } & $\Delta$ T max. $[\mathrm{K}]$ & 13.78 & 13.14 & 2.16 & 1.18 & 10.79 & 1.66 \\
& $\Delta$ T min. $[\mathrm{K}]$ & -4.43 & -2.88 & -2.00 & -0.88 & -3.09 & -0.32 \\
& $\Delta$ T average $[\mathrm{K}]$ & -0.02 & 0.55 & 0.04 & 0.12 & 0.63 & 0.14 \\
& RMSE $[-]$ & 1.37 & 1.59 & 0.71 & 0.29 & 1.42 & 0.21 \\
\hline
\end{tabular}

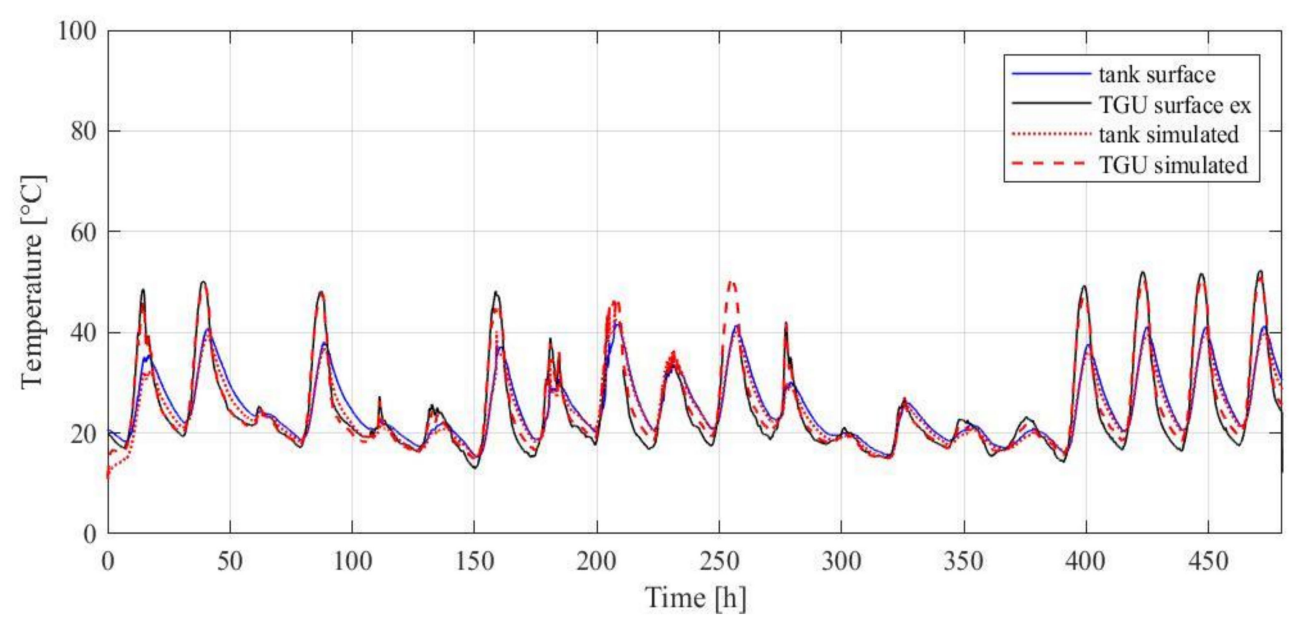

(a)

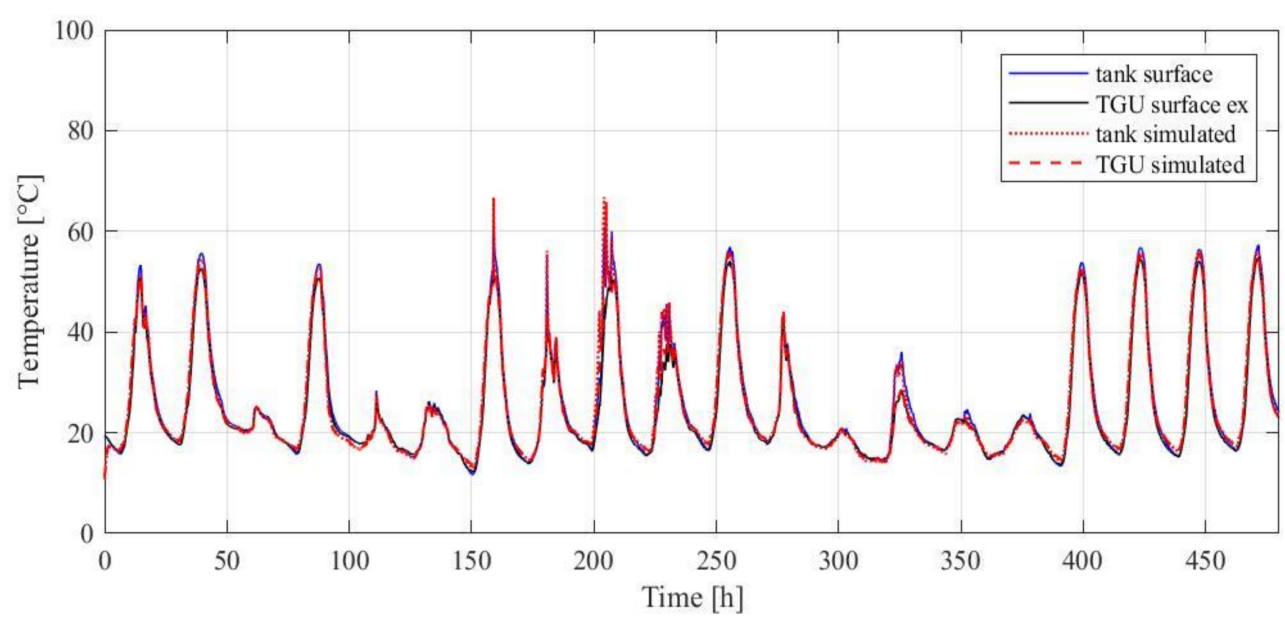

(b)

Figure 7. Predicted and measured temperatures as in Figure 5, but with refined and calibrated model. $\mathrm{SEBF}_{\mathrm{w}}(\mathbf{a})$ and $\mathrm{SEBF}_{\mathrm{a}}(\mathbf{b})$ elements during summer weeks (80\% water filling). 
Table 3. Statistics of the differences between simulated and measured temperatures [K] of the tank for $\mathrm{SEBF}_{\mathrm{w}}$, starting from the 24th hour of simulation at intervals of one minute.

\begin{tabular}{llcccccc}
\hline & $\begin{array}{c}\text { Tank } \\
\text { Surface }\end{array}$ & $\begin{array}{c}\text { Tank Core } \\
\text { (Air) }\end{array}$ & $\begin{array}{c}\text { Parapet } \\
\text { Insulation } \\
\text { Core }\end{array}$ & $\begin{array}{c}\text { Parapet } \\
\text { Inner } \\
\text { Surface }\end{array}$ & $\begin{array}{c}\text { TGU } \\
\text { External } \\
\text { Surface }\end{array}$ & $\begin{array}{c}\text { TGU } \\
\text { Internal } \\
\text { Surface }\end{array}$ \\
\hline \multirow{5}{*}{ Winter } & $\Delta$ T max. $[\mathrm{K}]$ & 4.90 & 1.32 & 1.00 & 1.18 & 1.46 & 1.06 \\
& $\Delta$ T min. $[\mathrm{K}]$ & -5.53 & -5.02 & -3.11 & -1.69 & -6.00 & -1.42 \\
& $\Delta$ T average $[\mathrm{K}]$ & -0.65 & 0.19 & -0.46 & 0.02 & -0.89 & -0.85 \\
& RMSE $[-]$ & 1.24 & 0.68 & 0.70 & 0.26 & 1.22 & 0.91 \\
\hline \multirow{5}{*}{ Summer } & $\Delta$ T max. $[\mathrm{K}]$ & 8.75 & 2.66 & 1.64 & 1.10 & 4.01 & 0.82 \\
& $\Delta$ T min. $[\mathrm{K}]$ & -3.88 & -5.86 & -1.36 & -1.05 & -3.50 & -1.07 \\
& $\Delta$ T average $[\mathrm{K}]$ & -0.70 & -0.29 & -0.23 & 0.06 & 0.23 & -0.55 \\
& RMSE $[-]$ & 1.26 & 0.86 & 0.53 & 0.31 & 1.15 & 0.57 \\
\hline
\end{tabular}

\subsection{Simulation-Based Performance Assessment}

The performance of the SEBF with and without thermal storage $\left(\mathrm{SEBF}_{\mathrm{w}}\right.$ and $\left.\mathrm{SEBF}_{\mathrm{a}}\right)$ was evaluated assuming an attached test cell [12]. The cell's south-facing wall was completely replaced by a side-by-side installation of either two SEBF water or two SEBF air elements. The integral energy balance of the HVAC unit was simulated. For all locations, the same model with identical set points was used.

\subsubsection{Locations}

Zurich (Switzerland), Stockholm (Sweden), Madrid (Spain), and London (United Kingdom) were chosen as locations for an exemplary performance evaluation of the SEBF. The four locations are identical to those included in an earlier study, [23], and cover a wide range of climatic conditions in Europe. Meteorological data provided by Meteonorm was used [20]. Tables 4 and 5 give an overview of the monthly average external air temperatures and total solar irradiation on a south-facing vertical façade for all locations.

Table 4. Average external air temperature from $[20]$ in $\left[{ }^{\circ} \mathrm{C}\right]$.

\begin{tabular}{ccccc}
\hline & Zurich & Stockholm & Madrid & London \\
\hline January & 2.0 & -1.0 & 6.7 & 7.3 \\
February & 2.8 & -1.8 & 8.3 & 7.3 \\
March & 5.5 & 0.7 & 11.8 & 9.0 \\
April & 9.0 & 6.0 & 13.8 & 11.6 \\
May & 13.8 & 11.3 & 18.7 & 15.1 \\
June & 17.5 & 15.4 & 24.9 & 18.2 \\
July & 18.8 & 18.9 & 27.5 & 20.0 \\
August & 18.7 & 18.0 & 27.0 & 20.0 \\
September & 14.6 & 12.6 & 22.1 & 17.0 \\
October & 10.8 & 7.5 & 16.6 & 13.6 \\
November & 5.3 & 3.3 & 10.1 & 10.1 \\
December & 2.7 & 0.4 & 7.1 & 7.6 \\
\hline Year & 10.2 & 7.7 & 16.3 & 13.1 \\
\hline
\end{tabular}


Table 5. Solar irradiance on vertical south-facing façade from [20] in [MJm $\left.{ }^{-2}\right]$.

\begin{tabular}{ccccc}
\hline & Zurich & Stockholm & Madrid & London \\
\hline January & 187 & 131 & 387 & 156 \\
February & 253 & 208 & 385 & 177 \\
March & 363 & 356 & 462 & 258 \\
April & 338 & 381 & 365 & 282 \\
May & 305 & 397 & 307 & 307 \\
June & 298 & 374 & 297 & 271 \\
July & 313 & 383 & 330 & 287 \\
August & 332 & 379 & 397 & 324 \\
September & 337 & 340 & 436 & 295 \\
October & 264 & 225 & 422 & 252 \\
November & 178 & 110 & 374 & 179 \\
December & 170 & 78 & 328 & 128 \\
\hline Year & 3338 & 3360 & 4490 & 2914 \\
\hline
\end{tabular}

\subsubsection{Shading Control}

The shading control enters three predefined modes based on the mean average external temperature over the last $24 \mathrm{~h}$ (T24).

Winter mode is active when $\mathrm{T} 24<12{ }^{\circ} \mathrm{C}$, and configures the SEBF so that

- both shading devices are closed at nighttime when solar irradiation is $\leq 25 \mathrm{Wm}^{-2}$,

- the parapet shading device opens the whole day (solar irradiation is $>25 \mathrm{Wm}^{-2}$ ), and

- the TGU shading device is closed when solar irradiation is $>350 \mathrm{Wm}^{-2}$.

Summer mode is active when $\mathrm{T} 24>15^{\circ} \mathrm{C}$, and configures the SEBF so that

- both shading devices are open at nighttime when solar irradiation is $\leq 25 \mathrm{Wm}^{-2}$,

- the parapet shading device is closed the whole day (solar irradiation is $>25 \mathrm{Wm}^{-2}$ ), and

- the TGU shading device is closed when solar irradiation is $>150 \mathrm{Wm}^{-2}$.

Free float mode is active in between these seasons when $12{ }^{\circ} \mathrm{C} \leq \mathrm{T} 24 \leq 15^{\circ} \mathrm{C}$, and aims to prevent overheating the storage but allows higher direct solar gains:

- the parapet shading device is open at nighttime $\left(\leq 25 \mathrm{Wm}^{-2}\right)$ and closed the whole day $\left(>25 \mathrm{Wm}^{-2}\right)$, and

- the TGU shading device is closed at nighttime $\left(\leq 25 \mathrm{Wm}^{-2}\right)$ and closed when solar irradiation is $>350 \mathrm{Wm}^{-2}$.

\subsubsection{HVAC Control}

The test cell is equipped with an HVAC unit, modeled with a rated power of $1000 \mathrm{~W}$ in heating and cooling mode. Due to a lack of documentation, the device's control schedule was modeled based on the observed operation in the test cell [12], as illustrated by Figure 8. The HVAC unit has a dead band of about $\pm 1.5 \mathrm{~K}$ to the set point $\left(22^{\circ} \mathrm{C}\right.$ in the model). If room air temperature exceeds the dead band, the heating or cooling mode is activated until the room air temperature reaches the max or min temperature set point $\left(24^{\circ} \mathrm{C}\right.$ or $20^{\circ} \mathrm{C}$, respectively, in the model).

Switching between the two modes is delayed by about $15 \mathrm{~min}$, e.g., the cooling mode is entered $15 \mathrm{~min}$ before the heating mode is abandoned. The observed drift of the effective set points over time makes it impossible to directly use them for model calibration. Even short delays have an effect in particular predicted temperatures at the interior surfaces and layers of the prototypes and, therefore, lead to substantial statistical differences. Nevertheless, the comparison of the measured data and simulation SEBF in the context of the test cell showed good overall agreement. 


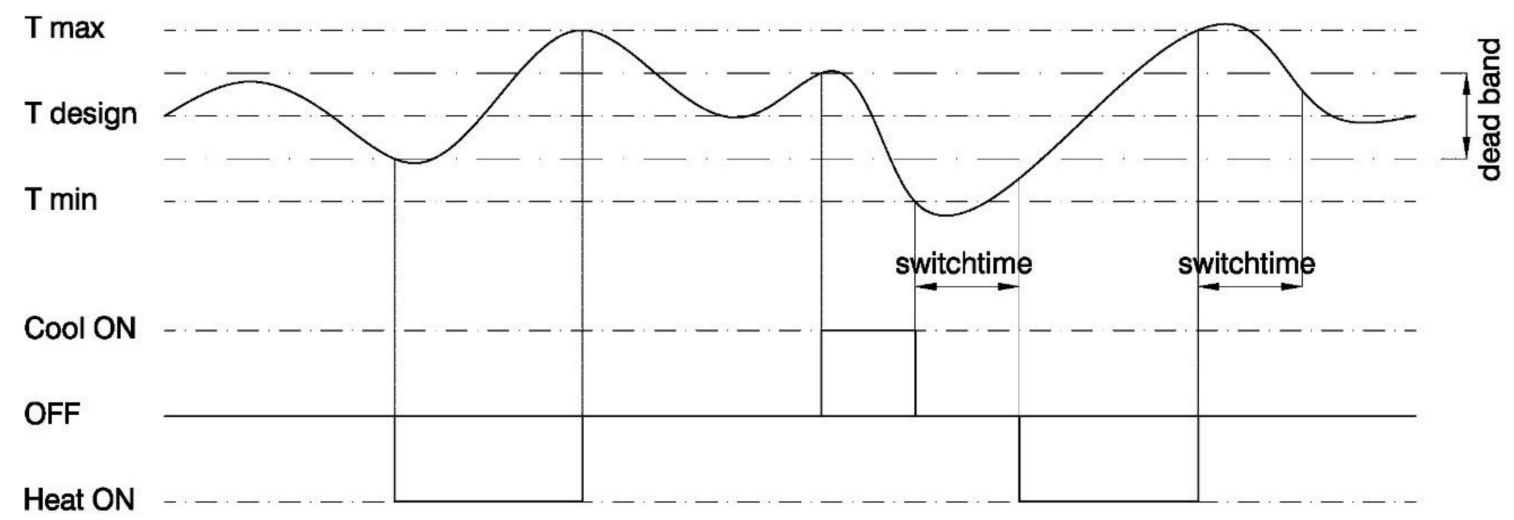

Figure 8. Operation pattern of the HVAC controlled by set points for room air temperature.

\section{Results}

The following sections present the results of an annual simulation of the test cell [12] equipped with the SEBF with either two water-filled or two empty storage tanks. The SEBF shading control is applied as described in Section 2.4.2 and the HVAC control according to Section 2.4.3. All other independent variables but the local climate (solar irradiation, temperature, and wind speed) are constant. Due to the low U-value $\left(0.08 \mathrm{Wm}^{-2} \mathrm{~K}^{-1}\right)$ of the test cell's walls, the major heat flows occur through the SEBF. Both configurations of the SEBF, with $\left(\mathrm{SEBF}_{\mathrm{w}}\right)$ and without storage $\left(\mathrm{SEBF}_{\mathrm{a}}\right)$, are strongly dependent on the incident solar irradiation, accumulate solar energy in wintertime, and minimize solar gains in summertime. The results for each location are reported in two sections:

- The particular impact of solar irradiance for the test box equipped with a south façade comprising two $\mathrm{SEBF}_{\mathrm{w}}$ elements. The results are compared under conditions given by the climate data, and otherwise identical conditions, but with solar irradiance set to zero to determine the influence of direct solar gains.

- For an analysis of the effects of the SEBF's thermal mass, the energy demand for cooling and heating for its two configurations $\left(\mathrm{SEBF}_{\mathrm{w}}\right.$ and $\left.\mathrm{SEBF}_{\mathrm{a}}\right)$ is presented. The effect of the thermal storage on the operation of the HVAC unit is a convolution of the intended moderation of heat transfers through the SEBF and the general dampening of heat transfer fluctuations by the thermal mass in the façade.

\subsection{Zurich}

The exclusion of solar irradiation implies that solar gains and, therefore, the energy demand for cooling are eliminated. In this case, the annual heating demand is $1052 \mathrm{kWh}$ (column "No sun" of Table 6). It decreases by $512 \mathrm{kWh}$ (column " $\Delta$ "), or $49 \%$ (column "Reduction SEBF \%"), to $540 \mathrm{kWh}$ when solar irradiation is accounted for (column "With sun"). $60 \%$ of this decrease is due to $309 \mathrm{kWh}$ of direct solar gains (column "Dir. Sol. Gain"). In wintertime, the contribution of direct solar gains to the effect of solar irradiation (column "\% Dir. Sol. Gain") is only about $42 \%$, even though TGU covers about $56 \%$ of the façade.

Table 7 shows the result summary of the monthly and annual heating and cooling demand for $\mathrm{SEBF}_{\mathrm{w}}$ and $\mathrm{SEBF}_{\mathrm{a}}$. In addition, the water's monthly, seasonal, and annual relative effects are reported. The introduction of $120 \mathrm{~L}$ of water $(60 \mathrm{~L}$ in each tank) decreases the annual heating and cooling demand by about $6 \%$ and $14 \%$, respectively. 
Table 6. Moderation of heat flows due to solar irradiation in Zurich. Predicted energy demand for heating with $\mathrm{SEBF}_{\mathrm{w}}$ with (sun) and without (no sun) provision for solar irradiation.

\begin{tabular}{|c|c|c|c|c|c|c|c|c|}
\hline & \multicolumn{3}{|c|}{ Heating Demand [kWh] } & \multirow{2}{*}{$\begin{array}{l}\text { Dir. Sol. } \\
\text { Gain }\end{array}$} & \multirow{2}{*}{\multicolumn{2}{|c|}{$\begin{array}{c}\text { Reduction SEBF } \\
\%^{1}\end{array}$}} & \multirow{2}{*}{\multicolumn{2}{|c|}{$\begin{array}{c}\text { Direct Solar Gain } \\
\% \text { of } \Delta\end{array}$}} \\
\hline & No Sun & With Sun & $\Delta$ & & & & & \\
\hline December & 154.2 & 118.6 & -35.6 & -13.2 & $-23.1 \%$ & & $37.2 \%$ & \\
\hline January & 161.0 & 117.9 & -43.2 & -18.0 & $-26.8 \%$ & $-30.0 \%$ & $42.1 \%$ & $42.0 \%$ \\
\hline February & 140.1 & 82.4 & -57.7 & -25.9 & $-41.2 \%$ & & $44.8 \%$ & \\
\hline March & 130.8 & 63.8 & -67.0 & -24.5 & $-51.2 \%$ & & $36.6 \%$ & \\
\hline April & 97.0 & 28.4 & -68.6 & -42.0 & $-70.7 \%$ & $-65.4 \%$ & $61.2 \%$ & $57.1 \%$ \\
\hline May & 54.7 & 5.6 & -49.1 & -38.9 & $-89.8 \%$ & & $79.3 \%$ & \\
\hline June & 27.1 & 1.5 & -25.6 & -29.0 & & & & \\
\hline July & 15.5 & 0.2 & -15.3 & -21.3 & & & & \\
\hline August & 16.5 & 1.2 & -15.3 & -21.0 & & & & \\
\hline September & 47.5 & 7.9 & -39.6 & -21.2 & $-83.3 \%$ & & $53.5 \%$ & \\
\hline October & 82.2 & 31.5 & -50.7 & -29.6 & $-61.7 \%$ & $-52.9 \%$ & $58.4 \%$ & $55.6 \%$ \\
\hline November & 125.5 & 80.9 & -44.6 & -24.2 & $-35.6 \%$ & & $54.2 \%$ & \\
\hline Year & 1052.2 & 539.8 & -512.4 & -309.0 & $-48.7 \%$ & & $60.3 \%$ & \\
\hline
\end{tabular}

Table 7. Effect of thermal mass in the SEBF in Zurich. Predicted energy demand for heating and cooling $\mathrm{SEBF}_{\mathrm{w}}$ and $\mathrm{SEBF}_{\mathrm{a}}$.

\begin{tabular}{|c|c|c|c|c|c|c|c|c|}
\hline & \multicolumn{4}{|c|}{ Heating Demand [kWh] } & \multicolumn{4}{|c|}{ Cooling Demand [kWh] } \\
\hline & $\mathrm{SEBF}_{\mathrm{w}}$ & $\mathrm{SEBF}_{\mathrm{a}}$ & $\% \mathrm{~h}$ & Vater & $\mathrm{SEBF}_{\mathrm{w}}$ & $\mathrm{SEBF}_{\mathrm{a}}$ & $\% V$ & ater \\
\hline December & 118.6 & 121.5 & $-2.3 \%$ & & -0.5 & -0.6 & $-28.3 \%$ & \\
\hline January & 117.9 & 121.0 & $-2.6 \%$ & $-3.2 \%$ & -1.1 & -1.3 & $-13.1 \%$ & $-22.4 \%$ \\
\hline February & 82.4 & 87.0 & $-5.3 \%$ & & -0.8 & -1.2 & $-29.4 \%$ & \\
\hline March & 63.8 & 69.6 & $-8.3 \%$ & & -0.6 & -0.9 & $-27.4 \%$ & \\
\hline April & 28.4 & 35.0 & $-18.6 \%$ & $-13.0 \%$ & -10.0 & -12.1 & $-17.7 \%$ & $-16.0 \%$ \\
\hline May & 5.6 & 7.9 & $-29.4 \%$ & & -9.8 & -11.3 & $-13.4 \%$ & \\
\hline June & 1.5 & 2.3 & $-34.4 \%$ & & -15.5 & -17.3 & $-10.3 \%$ & \\
\hline July & 0.2 & 0.5 & $-66.6 \%$ & $-30.6 \%$ & -15.4 & -17.1 & $-10.1 \%$ & $-10.6 \%$ \\
\hline August & 1.2 & 1.4 & $-12.3 \%$ & & -17.0 & -19.1 & $-11.2 \%$ & \\
\hline September & 7.9 & 10.5 & $-24.4 \%$ & & -3.4 & -4.8 & $-29.4 \%$ & \\
\hline October & 31.5 & 35.3 & $-10.9 \%$ & $-7.5 \%$ & -6.6 & -7.7 & $-14.3 \%$ & $-20.8 \%$ \\
\hline November & 80.9 & 84.2 & $-4.0 \%$ & & -2.9 & -3.8 & $-23.2 \%$ & \\
\hline Year & 539.8 & 576.1 & $-6.3 \%$ & & -83.6 & -97.2 & $14.0 \%$ & - \\
\hline
\end{tabular}

\subsection{Stockholm}

As Tables 4 and 5 indicate, the climate in Stockholm is close to that of Zurich, but slightly colder, with less solar irradiance on the façade. This is reflected by the comparable impact of the moderation of solar irradiance on heating energy, decreasing from about $1296 \mathrm{kWh}$ to $770 \mathrm{kWh}$ when solar irradiation is accounted for (Table 8). Annual direct solar gains make up 59\% of the effects of solar irradiation.

The impact of the water-fill's thermal mass is reported in Table 9. Differences between $\mathrm{SEBF}_{\mathrm{w}}$ and $\mathrm{SEBF}_{\mathrm{a}}$ are low for all seasons but summer. This indicates that, due to the colder climate and slightly lower solar irradiance, the effectivity of the thermal mass in reducing outward heat losses is lower. In summer, the reported effects on heating demand are greater but relative to very low absolute values. The effect of the water's thermal mass on cooling demand is a $14 \%$ reduction. 
Table 8. Moderation of heat flows due to solar irradiation in Stockholm. Predicted energy demand for heating with $\mathrm{SEBF}_{\mathrm{w}}$ with (sun) and without (no sun) provision for solar irradiation.

\begin{tabular}{|c|c|c|c|c|c|c|c|c|}
\hline & \multicolumn{3}{|c|}{ Heating Demand [kWh] } & \multirow{2}{*}{$\begin{array}{l}\text { Dir. Sol. } \\
\text { Gain }\end{array}$} & \multicolumn{2}{|c|}{ Reduction SEBF } & \multirow{2}{*}{\multicolumn{2}{|c|}{$\frac{\text { Direct Solar Gain }}{\text { No Sun }}$}} \\
\hline & No Sun & With Sun & $\Delta$ & & & & & \\
\hline December & 176.4 & 146.3 & -30.2 & -17.9 & $-17.1 \%$ & & $59.4 \%$ & \\
\hline January & 188.6 & 154.2 & -34.4 & -15.5 & $-18.2 \%$ & $-20.5 \%$ & $45.0 \%$ & $47.1 \%$ \\
\hline February & 176.6 & 129.9 & -46.7 & -19.0 & $-26.5 \%$ & & $40.6 \%$ & \\
\hline March & 173.2 & 96.7 & -76.5 & -32.7 & $-44.2 \%$ & & $42.7 \%$ & \\
\hline April & 120.0 & 43.3 & -76.7 & -40.3 & $-63.9 \%$ & $-59.1 \%$ & $52.6 \%$ & $53.2 \%$ \\
\hline May & 77.9 & 11.7 & -66.2 & -43.8 & $-84.9 \%$ & & $66.1 \%$ & \\
\hline June & 37.9 & 1.2 & -36.7 & -27.6 & & & & \\
\hline July & 11.5 & 0.0 & -11.5 & -21.3 & & & & \\
\hline August & 17.3 & 0.2 & -17.2 & -18.5 & & & & \\
\hline September & 61.6 & 13.8 & -47.8 & -29.2 & $-77.6 \%$ & & $61.0 \%$ & \\
\hline October & 111.0 & 58.1 & -53.0 & -29.5 & $-47.7 \%$ & $-41.0 \%$ & $55.6 \%$ & $55.5 \%$ \\
\hline November & 144.2 & 114.9 & -29.3 & -13.5 & $-20.3 \%$ & & $46.1 \%$ & \\
\hline Year & 1296.5 & 770.3 & -526.2 & -308.6 & $-40.6 \%$ & & $58.7 \%$ & \\
\hline
\end{tabular}

Table 9. Effect of thermal mass in the SEBF in Stockholm. Predicted energy demand for heating and cooling with $\mathrm{SEBF}_{\mathrm{w}}$ and $\mathrm{SEBF}_{\mathrm{a}}$.

\begin{tabular}{|c|c|c|c|c|c|c|c|c|}
\hline & \multicolumn{4}{|c|}{ Heating Demand [kWh] } & \multicolumn{4}{|c|}{ Cooling Demand [kWh] } \\
\hline & $\mathrm{SEBF}_{\mathrm{w}}$ & $\mathrm{SEBF}_{\mathrm{a}}$ & $\% \mathrm{~W}$ & ater & $\mathrm{SEBF}_{\mathrm{w}}$ & $\mathrm{SEBF}_{\mathrm{a}}$ & $\% \mathrm{~W}$ & ater \\
\hline December & 146.3 & 146.6 & $-0.3 \%$ & & -0.8 & -1.0 & $-19.8 \%$ & \\
\hline January & 154.2 & 155.8 & $-1.0 \%$ & $-1.1 \%$ & -0.3 & -0.3 & $-24.9 \%$ & $-22.4 \%$ \\
\hline February & 129.9 & 132.7 & $-2.1 \%$ & & -0.2 & -0.3 & $-28.3 \%$ & \\
\hline March & 96.7 & 102.6 & $-5.7 \%$ & & -2.0 & -2.1 & $-7.9 \%$ & \\
\hline April & 43.3 & 49.6 & $-12.7 \%$ & $-9.5 \%$ & -7.9 & -9.0 & $-12.1 \%$ & $-10.6 \%$ \\
\hline May & 11.7 & 15.5 & $-24.4 \%$ & & -10.8 & -11.9 & $-9.9 \%$ & \\
\hline June & 1.2 & 2.2 & $-44.0 \%$ & & -7.3 & -8.8 & $-16.9 \%$ & \\
\hline July & 0.0 & 0.0 & - & $-44.8 \%$ & -19.6 & -21.4 & $-8.4 \%$ & $-11.7 \%$ \\
\hline August & 0.2 & 0.3 & $-50.7 \%$ & & -12.0 & -13.8 & $-13.6 \%$ & \\
\hline September & 13.8 & 18.1 & $-23.4 \%$ & & -10.0 & -12.0 & $-17.1 \%$ & \\
\hline October & 58.1 & 64.6 & $-10.1 \%$ & $-6.2 \%$ & -5.9 & -8.3 & $-28.9 \%$ & $-22.1 \%$ \\
\hline November & 114.9 & 116.5 & $-1.3 \%$ & & -0.2 & -0.3 & $-32.2 \%$ & \\
\hline Year & 770.3 & 804.4 & $-4.2 \%$ & & -76.9 & -89.4 & $-14.0 \%$ & \\
\hline
\end{tabular}

\subsection{Madrid}

Madrid is the southernmost location in this study and, with an annual average temperature of $16.3^{\circ} \mathrm{C}$, the warmest. As Table 5 indicated, a south-facing façade in Madrid receives significantly more solar energy in wintertime than in all other locations, but a similar amount in summertime mainly due to a higher sun elevation. Due to higher exterior air temperatures, a simulation excluding the effects of solar irradiation results in an annual cooling demand of $124 \mathrm{kWh}$. The annual heating demand without sun is $594 \mathrm{kWh}$. Accounting for solar irradiation decreases the annual heating demand by $67 \%$, to $195 \mathrm{kWh}$, whereas $57 \%$ of the effect is due to direct solar gains (see Table 10) and, consequently, increases cooling demand to $302 \mathrm{kWh}$ (see Table 11). 
Table 10. Moderation of heat flows due to solar irradiation in Madrid. Predicted energy demand for heating with $\mathrm{SEBF}_{\mathrm{w}}$ with (sun) and without (no sun) provision for solar irradiation.

\begin{tabular}{|c|c|c|c|c|c|c|c|c|}
\hline & \multicolumn{3}{|c|}{ Heating Demand [kWh] } & \multirow{2}{*}{$\begin{array}{l}\text { Dir. Sol. } \\
\text { Gain }\end{array}$} & \multicolumn{2}{|c|}{ Reduction SEBF } & \multirow{2}{*}{\multicolumn{2}{|c|}{$\begin{array}{c}\text { Direct Solar Gain } \\
\text { No Sun }\end{array}$}} \\
\hline & No Sun & With Sun & $\Delta$ & & & & & \\
\hline December & 115.3 & 52.9 & -62.4 & -23.7 & $-54.2 \%$ & & $38.0 \%$ & \\
\hline January & 118.5 & 53.5 & -65.0 & -20.3 & $-54.8 \%$ & $-57.9 \%$ & $31.3 \%$ & $35.4 \%$ \\
\hline February & 94.6 & 31.9 & -62.6 & -23.2 & $-66.2 \%$ & & $37.0 \%$ & \\
\hline March & 74.4 & 16.0 & -58.4 & -25.2 & $-78.5 \%$ & & $43.1 \%$ & \\
\hline April & 52.8 & 8.5 & -44.3 & -28.8 & $-83.9 \%$ & $-82.4 \%$ & $65.1 \%$ & $63.0 \%$ \\
\hline May & 23.4 & 2.0 & -21.4 & -24.2 & $-91.5 \%$ & & $112.6 \%$ & \\
\hline June & 0.1 & 0.0 & -0.1 & -16.9 & - & & & \\
\hline July & 0.0 & 0.0 & - & -15.8 & - & - & & - \\
\hline August & 0.0 & 0.0 & - & -9.9 & - & & & \\
\hline September & 1.5 & 0.0 & -1.5 & -6.0 & $-100.0 \%$ & & $401.5 \%$ & \\
\hline October & 30.2 & 2.7 & -27.5 & -13.4 & $-90.9 \%$ & $-74.4 \%$ & $48.6 \%$ & $47.9 \%$ \\
\hline November & 83.6 & 26.8 & -56.8 & -21.7 & $-67.9 \%$ & & $38.2 \%$ & \\
\hline Year & 594.6 & 194.4 & -400.2 & -229.2 & $-67.3 \%$ & & $57.3 \%$ & \\
\hline
\end{tabular}

The higher solar irradiation in wintertime increases the impact of the water-fill's thermal mass in the storage tank. As shown in Table 11, $\mathrm{SEBF}_{\mathrm{a}}$ causes a cooling demand of about 4 to $7 \mathrm{kWh}$ even in wintertime. This indicates a significant higher overheating risk, requiring the operation of the HVAC unit for cooling even in winter. This can be mitigated by the water's thermal mass, reducing cooling energy demand in winter by $40 \%$, to 3 to $4 \mathrm{kWh}$. Heating energy demand in winter can be reduced by $17 \%$, which is higher compared to colder climates but relates to lower absolute values. The efficiency of the water tank in reducing cooling energy demand other than in winter is low. The annual reduction is only $-7 \%$. This can be explained by high irradiation along with high external temperatures in summer quickly charging the storage, combined with high night temperatures that do not allow the storage to cool down, in particular in summer, when cooling demand is highest.

Table 11. Effect of thermal mass in the SEBF in Madrid. Predicted energy demand for heating and cooling with $\mathrm{SEBF}_{\mathrm{w}}$ and $\mathrm{SEBF}_{\mathrm{a}}$.

\begin{tabular}{|c|c|c|c|c|c|c|c|c|}
\hline & \multicolumn{4}{|c|}{ Heating Demand [kWh] } & \multicolumn{4}{|c|}{ Cooling Demand [kWh] } \\
\hline & SEBF $_{w}$ & $\mathrm{SEBF}_{\mathrm{a}}$ & $\% \mathrm{~V}$ & Jater & $\mathrm{SEBF}_{\mathrm{w}}$ & $\mathrm{SEBF}_{\mathrm{a}}$ & $\% \mathrm{~V}$ & ater \\
\hline December & 52.9 & 62.3 & $-15.2 \%$ & & -3.7 & -6.2 & $-40.7 \%$ & \\
\hline January & 53.5 & 62.6 & $-14.6 \%$ & $-16.8 \%$ & -2.8 & -4.2 & $-34.4 \%$ & $-39.9 \%$ \\
\hline February & 31.9 & 41.4 & $-22.7 \%$ & & -4.1 & -7.1 & $-42.4 \%$ & \\
\hline March & 16.0 & 21.8 & $-26.5 \%$ & & -5.9 & -7.9 & $-26.1 \%$ & \\
\hline April & 8.5 & 11.0 & $-22.6 \%$ & $-25.5 \%$ & -8.1 & -9.7 & $-16.6 \%$ & $-13.0 \%$ \\
\hline May & 2.0 & 2.8 & $-29.3 \%$ & & -19.7 & -21.0 & $-6.3 \%$ & \\
\hline June & 0.0 & 0.0 & - & & -57.4 & -58.5 & $-1.8 \%$ & \\
\hline July & 0.0 & 0.0 & - & - & -82.0 & -82.7 & $-0.9 \%$ & $-1.3 \%$ \\
\hline August & 0.0 & 0.0 & - & & -74.9 & -76.0 & $-1.5 \%$ & \\
\hline September & 0.0 & 0.0 & - & & -32.3 & -34.3 & $-5.6 \%$ & \\
\hline October & 2.7 & 4.5 & $-38.5 \%$ & $-25.0 \%$ & -5.8 & -7.8 & $-26.0 \%$ & $-12.9 \%$ \\
\hline November & 26.8 & 34.9 & $-23.2 \%$ & & -5.0 & -7.5 & $-32.8 \%$ & \\
\hline Year & 194.4 & 241.4 & $-19.4 \%$ & & -301.6 & -322.9 & $-6.6 \%$ & \\
\hline
\end{tabular}

\subsection{London}

London differs significantly from all other evaluated locations because of its well-balanced climate (Table 4). The total annual solar irradiation is the lowest of all four locations. Accounting for heat flows due to solar irradiance in the model causes a decrease of heating energy demand from $740 \mathrm{kWh}$ to 
$340 \mathrm{kWh}$ (Table 12). This apparently high difference of $-54 \%$, however, corresponds to an absolute impact of only $403 \mathrm{kWh}$. $74 \%$ of the annual heating demand reduction is due to direct solar gains.

Table 12. Moderation of heat flows due to solar irradiation in London. Predicted energy demand for heating with $\mathrm{SEBF}_{\mathrm{W}}$ with (sun) and without (no sun) provision for solar irradiation.

\begin{tabular}{|c|c|c|c|c|c|c|c|c|}
\hline & \multicolumn{3}{|c|}{ Heating Demand [kWh] } & \multirow{2}{*}{$\begin{array}{l}\text { Dir. Sol. } \\
\text { Gain }\end{array}$} & \multicolumn{2}{|c|}{ Reduction SEBF } & \multirow{2}{*}{\multicolumn{2}{|c|}{$\frac{\text { Direct Solar Gain }}{\text { No Sun }}$}} \\
\hline & No Sun & With Sun & $\Delta$ & & & & & \\
\hline December & 111.3 & 78.6 & -32.7 & -17.3 & $-29.4 \%$ & & $53.1 \%$ & \\
\hline January & 112.9 & 78.9 & -33.9 & -14.7 & $-30.1 \%$ & $-34.7 \%$ & $43.4 \%$ & $51.6 \%$ \\
\hline February & 102.9 & 55.9 & -46.9 & -26.5 & $-45.6 \%$ & & $56.4 \%$ & \\
\hline March & 99.4 & 40.1 & -59.3 & -37.5 & $-59.6 \%$ & & $63.3 \%$ & \\
\hline April & 71.8 & 14.4 & -57.4 & -43.5 & $-80.0 \%$ & $-73.5 \%$ & $75.8 \%$ & $75.6 \%$ \\
\hline May & 45.4 & 3.0 & -42.5 & -39.3 & $-93.5 \%$ & & $92.5 \%$ & \\
\hline June & 18.8 & 0.0 & -18.8 & -24.6 & & & & \\
\hline July & 8.1 & 0.0 & -8.1 & -20.1 & & & & \\
\hline August & 5.3 & 0.0 & -5.3 & -16.3 & & & & \\
\hline September & 25.5 & 3.3 & -22.2 & -13.9 & $-87.0 \%$ & & $62.7 \%$ & \\
\hline October & 56.3 & 17.0 & -39.3 & -23.8 & $-69.8 \%$ & $-59.2 \%$ & $60.6 \%$ & $59.4 \%$ \\
\hline November & 84.5 & 47.5 & -37.0 & -20.8 & $-43.8 \%$ & & $56.0 \%$ & \\
\hline Year & 742.2 & 338.8 & -403.4 & -298.4 & $-54.4 \%$ & & $74.0 \%$ & \\
\hline
\end{tabular}

Due to the well-balanced climate in London, the thermal mass of the water-fill decreases both annual heating and cooling energy demands by $-7 \%$ and $-13 \%$ respectively (Table 13 ). Seasonal results are more balanced than in other locations. For all seasons but summer, the combined energy demand for cooling and heating is consistently reduced by $28 \%$ to $31 \%$ due to the water-fill. In the summer, the moderate climate requires no heating and causes only a very low demand for cooling, that can be only minimally decreased by the storage.

Table 13. Effect of thermal mass in the SEBF in London. Predicted energy demand for heating and cooling with $\mathrm{SEBF}_{\mathrm{w}}$ and $\mathrm{SEBF}_{\mathrm{a}}$.

\begin{tabular}{|c|c|c|c|c|c|c|c|c|}
\hline & \multicolumn{4}{|c|}{ Heating Demand [kWh] } & \multicolumn{4}{|c|}{ Cooling Demand [kWh] } \\
\hline & $\mathrm{SEBF}_{\mathrm{w}}$ & $\mathrm{SEBF}_{\mathrm{a}}$ & $\% \mathrm{~W}$ & ater & $\mathrm{SEBF}_{\mathrm{w}}$ & $\mathrm{SEBF}_{\mathrm{a}}$ & $\% \mathrm{~V}$ & ater \\
\hline December & 78.6 & 80.6 & $-2.6 \%$ & & -2.0 & -2.5 & $-21.0 \%$ & \\
\hline January & 78.9 & 82.1 & $-3.9 \%$ & $-4.2 \%$ & -1.8 & -2.5 & $-25.7 \%$ & $-25.1 \%$ \\
\hline February & 55.9 & 60.0 & $-6.9 \%$ & & -3.4 & -4.6 & $-26.9 \%$ & \\
\hline March & 40.1 & 45.3 & $-11.5 \%$ & & -8.8 & -10.6 & $-17.0 \%$ & \\
\hline April & 14.4 & 18.5 & $-22.2 \%$ & $-16.0 \%$ & -13.5 & -15.5 & $-13.2 \%$ & $-14.9 \%$ \\
\hline May & 3.0 & 4.6 & $-36.0 \%$ & & -11.6 & -13.7 & $-15.3 \%$ & \\
\hline June & 0.0 & 0.0 & - & & -14.0 & -14.9 & $-6.1 \%$ & \\
\hline July & 0.0 & 0.0 & - & - & -20.1 & -21.6 & $-7.2 \%$ & $-7.5 \%$ \\
\hline August & 0.0 & 0.0 & - & & -18.4 & -20.1 & $-8.8 \%$ & \\
\hline September & 3.3 & 3.2 & $4.5 \%$ & & -4.8 & -5.0 & $-4.8 \%$ & \\
\hline October & 17.0 & 19.5 & $-12.6 \%$ & $-8.5 \%$ & -3.8 & -5.3 & $-29.0 \%$ & $-19.7 \%$ \\
\hline November & 47.5 & 51.5 & $-7.7 \%$ & & -4.7 & -6.1 & $-23.9 \%$ & \\
\hline Year & 338.8 & 365.4 & $-7.3 \%$ & & -106.8 & -122.6 & $-12.9 \%$ & \\
\hline
\end{tabular}

\section{Discussion}

\subsection{SEBF Suitability in Different Locations}

All results presented in Chapter 3 confirm the reduction of heat losses due to introduction of solar energy storage in a CCF. 
For wintertime (December to February), all locations show significant heating demand reductions of more than $21 \%$, that depend on local climate conditions (Table 14). E.g., the climate in Stockholm is characterized by lower air temperatures and reduced solar irradiance compared to other locations, which reduce the effect of the additional thermal mass of $\mathrm{SEBF}_{\mathrm{w}}$. In Madrid, heat loss reduction in wintertime is mainly driven by the store and release effect of $\mathrm{SEBF}_{\mathrm{w}}$.

Interpreting the reduced energy demand for heating requires taking into account that the SEBF contributes only $49 \%$ of the test cell's total heat losses under steady state conditions. For Madrid, the $\mathrm{SEBF}_{\mathrm{W}}$ reduced the wintertime energy loss by approximately $58 \%$, by a steady condition fraction of $49 \%$. This means that the SEBF is a plus energy façade in this period $(58 \% / 49 \%=118 \%)$. Only one third of this effect $(20 \% / 58 \%)$ is due to direct solar gains. For Zurich, Stockholm, and London, $\mathrm{SEBF}_{\mathrm{w}}$ reduced its own heat loss by $43 \%$ to $61 \%$ compared to steady state conditions. Direct solar gains account for $50 \%$ or less of the heating demand reduction.

Table 14. Effect on heating energy demand by $\mathrm{SEBF}_{\mathrm{w}}$ in wintertime (Dec-Feb) [kWh].

\begin{tabular}{cccccc}
\hline Location & $\begin{array}{c}\text { Heating } \\
\text { No Sun }\end{array}$ & $\begin{array}{c}\boldsymbol{\Delta} \\
\mathbf{S E B F}_{\mathbf{w}}\end{array}$ & Total \% & Direct \% & Storage \% \\
\hline Zurich) & 455.4 & -136.50 & $-30 \%$ & $-13 \%$ & $-17 \%$ \\
Stockholm & 541.7 & -111.30 & $-21 \%$ & $-10 \%$ & $-11 \%$ \\
Madrid & 328.4 & -190.02 & $-58 \%$ & $-20 \%$ & $-37 \%$ \\
London & 327.0 & -113.53 & $-35 \%$ & $-18 \%$ & $-17 \%$ \\
\hline
\end{tabular}

In summertime (June to August), the average external air temperature is lower than the room air temperature, and, therefore, heat losses occur, except for the case of Madrid (Table 15). In Madrid, almost no heat losses occur, even in the absence of solar irradiation. For all other locations, the direct solar gains are higher than the cooling demand. That means that they are mainly responsible for the cooling energy demand ( $>64 \%$, see Table 15$)$. In this context, a lower shading set point could significantly reduce cooling demands, but also reduce daylight use. On the other hand, a fully glazed element would produce even higher cooling loads.

Table 15. Effect on heating and cooling demand by $\mathrm{SEBF}_{\mathrm{w}}$ in summertime (Jun-Aug) [kWh].

\begin{tabular}{cccccc}
\hline Location & $\begin{array}{c}\text { Heating } \\
\text { No Sun }\end{array}$ & $\begin{array}{c}\text { Cooling } \\
\text { Demand }\end{array}$ & $|\boldsymbol{\Delta}|$ & $\begin{array}{c}\text { Direct Sol. } \\
\text { Gains }\end{array}$ & $\%$ of $\boldsymbol{\Delta}$ \\
\hline Zurich & 59.1 & -47.9 & 107.0 & 71.31 & $67 \%$ \\
Stockholm & 66.7 & -38.9 & 105.6 & 67.32 & $64 \%$ \\
Madrid & 0.1 & -214.3 & 214.5 & 42.60 & $20 \%$ \\
London & 32.2 & -52.5 & 84.7 & 61.04 & $72 \%$ \\
\hline
\end{tabular}

There is strong evidence that the SEBF supports seasonal needs. Heating demand decreases in winter due to solar energy use, and cooling demand is refunctioned in summer.

\subsection{Mass Effects on Heat Transfer}

To assess the SEBF's potential to balance heat flows through the façade, the effects of its thermal mass are discussed by comparing $\mathrm{SEBF}_{\mathrm{w}}$ and $\mathrm{SEBF}_{\mathrm{a}}$.

In wintertime, direct solar gains contribute $31 \%$ of the total heat loss reduction by $59 \%$ in the case of $\mathrm{SEBF}_{\mathrm{w}}$. Unfortunately, high direct solar gains also tend to overheat rooms and buildings. This effect is even worse in case of $\mathrm{SEBF}_{\mathrm{a}}$, when high direct solar gains coincide with high secondary solar heat gains though the parapet.

Figure 9 provides a detailed view of the inner surface heat flows of the two SEBF configurations. The negative peaks (heat loss) are caused by the HVAC unit, which heats the room up to $24{ }^{\circ} \mathrm{C}$ and 
is then turned off. For both $\mathrm{SEBF}_{\mathrm{w}}$ and $\mathrm{SEBF}_{\mathrm{a}}$, direct solar heat gains are identical, due to identical geometry and shading control. The differences between $\mathrm{SEBF}_{\mathrm{w}}$ and $\mathrm{SEBF}_{\mathrm{a}}$ are evident:

(a) $\mathrm{SEBF}_{\mathrm{a}}$ heats up in short time and causes high passive solar gains,

(b) the air tank causes a high upward heat flow and high passive gains through the TGU, while

(c) the water tank heats up slowly and induces less and delayed passive gains, and

(d) the TGU combined with $\mathrm{SEBF}_{\mathrm{w}}$ heats up less, since the water reduces passive gains.

It might be irritating that the water's effect is only about $-1 \%$ to $-4 \%$ in wintertime compared to $\mathrm{SEBF}_{\mathrm{a}}$. This is due to the short periods of high passive gains with $\mathrm{SEBF}_{\mathrm{a}}$, while periods of lower passive gains (loss reduction) by $\mathrm{SEBF}_{\mathrm{w}}$ are longer. While in total both heat flow integrals are similar, even short periods of high passive gains can lead to internal overheating and cooling loads, and potentially inacceptable discomfort.

The same effects cause the reduction of cooling demand in wintertime. Due to the lower and delayed passive gains, the risk of overheating is mitigated. Cooling energy demand is reduced by $13 \%$ up to $42 \%$ in wintertime (December to February). The thermal storage is not fully discharged toward the interior, and the solar gains are more effective with regard to heat loss reduction.

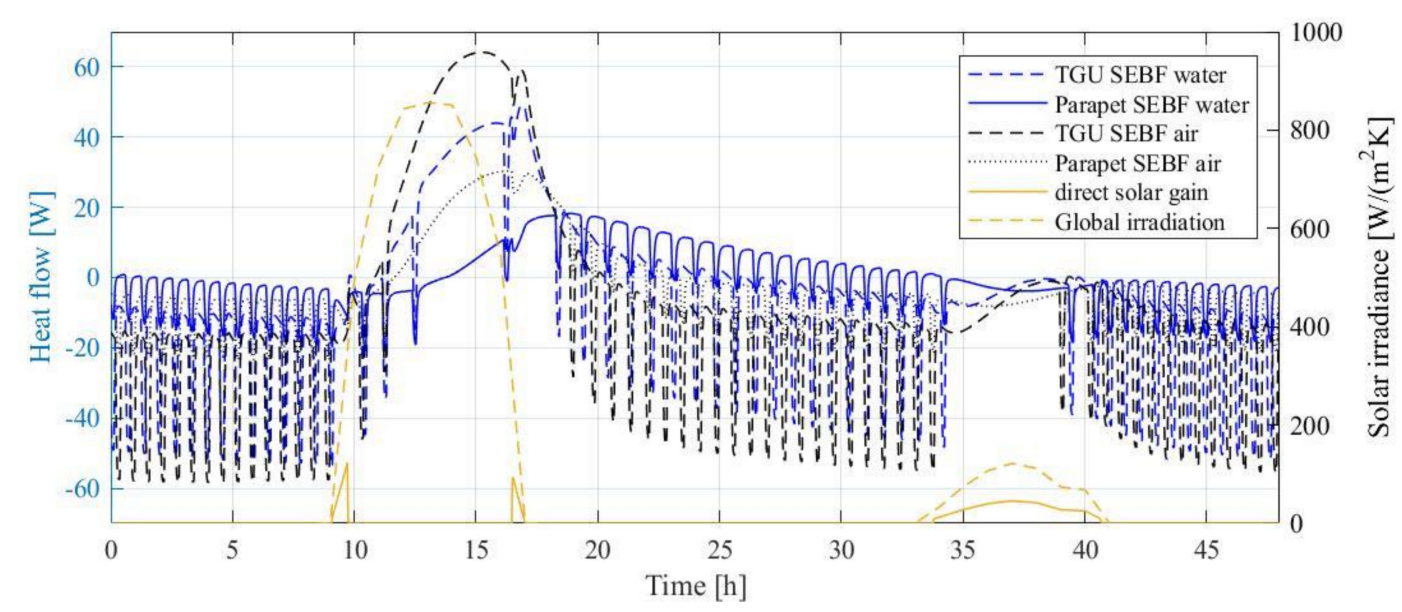

Figure 9. Detailed solar irradiance and heat flows on 2 and 3 January in Zurich, based on Meteonorm data; average external air temperature: $-2 \cdot 1^{\circ} \mathrm{C}$.

\subsection{Shading Control}

The control strategy of the shading device is based on initial experiences under conditions in Switzerland. For other locations, an adapted version could improve the efficiency of the SEBF. Nevertheless, the comparison of $\mathrm{SEBF}_{\mathrm{w}}$ and $\mathrm{SEBF}_{\mathrm{a}}$ indicated a consistent benefit for heating and cooling demand due to the integrated thermal storage. According to Table 16, the application of a $1.5 \mathrm{~m}^{2}$ storage tank with 120 liters of water could improve the annual energy demand of the test cell by $4 \%$ up to $19 \%$, depending on the location. In other words, 120 liters of water in an $8.6 \mathrm{~m}^{2}$ curtain wall could save 42 to $68 \mathrm{kWh}$ of effective HVAC energy, per year.

Table 16. SEBF water and SEBF air comparison result summary for all locations.

\begin{tabular}{ccccc}
\hline Location & $\begin{array}{c}\text { Annual Heating Load Reduction } \\
\text { [kWh] }\end{array}$ & $\begin{array}{c}\text { Annual Cooling Load Reduction } \\
\text { [kWh] }\end{array}$ \\
\hline Zurich & 36.3 & $-6.3 \%$ & 13.6 & $-14.0 \%$ \\
Stockholm & 34.1 & $-4.2 \%$ & 12.5 & $-14.0 \%$ \\
Madrid & 46.9 & $-19.4 \%$ & 21.3 & $-6.6 \%$ \\
London & 26.6 & $-7.3 \%$ & 15.8 & $-12.9 \%$ \\
\hline
\end{tabular}




\section{Conclusions}

This research demonstrates that utilizing solar thermal energy in façades can reduce heating demand not only by direct solar gains, but also by reduced heat losses. Furthermore, the thermal mass within the non-ventilated DSF cavity also reduces cooling demand in summertime, if there is a seasonal adaptive shading control. The delay of heat fluxes, due to the thermal mass balances and reduces the heating and cooling demand in the attached room.

As indicated by its name, the SEBF is a solar-dependent system. Without solar irradiance, the system acts as a poorly insulated wall with a $\mathrm{U}$-value of $0.7 \mathrm{Wm}^{-2} \mathrm{~K}^{-1}$. However, it is still the state of the art for a curtain wall. As regards solar irradiance, two types of solar gains occur: direct gains through the TGU and secondary gains due to the absorption within the façade. Usually, curtain wall façades, especially DSFs and CCFs, are designed to minimize solar absorption to avoid overheating.

In this study, only a south-facing façade was evaluated. Both $\mathrm{SEBF}_{\mathrm{w}}$ and $\mathrm{SEBF}_{\mathrm{a}}$ exhibited highly advantageous properties to reduce the heating and cooling demand of a building exposed to solar irradiation. The additional effect of managed solar thermal energy use improves the dynamic behavior of the façade significantly for winter and summer. The efficiency is strongly dependent on the local climate and façade orientation. If the external temperatures and solar irradiance are low in winter, the SEBF is less effective (e.g., in Stockholm). In the summer, high nighttime temperatures reduce the effect of the thermal mass (e.g., in Madrid). The research is limited to south-oriented façades. A more general evaluation may take other orientations into account, in particular due to the known high solar irradiation on east and west façades at lower latitudes.

However, the SEBF's primary aim is to use solar energy to reduce heat losses in the building and to achieve a seasonal response to relieve HVAC systems. Therefore, an adequate control strategy is needed. Currently, a simple approach distinguishes winter and summer modes based on the 24-h average outside air temperature. This allows decision-taking based only on exterior conditions. This approach is promising, because the façade is able to react before the HVAC is overstrained. Especially to prevent overheating, the façade could react before heat is stored in the building structure. Further improvements for control strategy, perhaps with the integration of internal variables, will be addressed.

The SEBF is currently at the prototype stage. Further storage materials and thicknesses shall be investigated. Due to freezing risk, the water filling is not suitable for all conditions, and evaporation issues have to be solved. Preliminary simulations with, e.g., concrete as storage showed promising results. However, concrete is a heavy material and causes a high dead load. An ideal material should be (i) lightweight, (ii) of high thermal storage capacity, (iii) easy to process, and (iv) architecturally appealing.

Addressing the observed problems of water-based thermal storage appears to be a worthwhile field for further research and development, given its potential for low-cost passive solar façades with little environmental impact. While other storage materials may achieve a better performance in terms of heating and cooling energy, such environmental aspects should be taken into account over the entire product life-cycle.

Author Contributions: Conceptualization, T.W.; data curation, T.W.; formal analysis, L.O.G.; funding acquisition, A.L. investigation, T.W. and A.L.; methodology, T.W. and L.O.G.; project administration, A.L.; resources, A.L.; supervision, A.L.; validation, T.W.; visualization, T.W.; writing, original draft, T.W.; writing, review and editing, L.O.G. and A.L. All authors have read and agreed to the published version of the manuscript.

Funding: This research was funded by the Swiss National Science Foundation, grant number IZCNZ0-174562, and was financially supported by the Swiss Innovation Agency Innosuisse, as part of the Swiss Competence Center for Energy Research SCCER FEEB\&D.

Acknowledgments: The authors gratefully acknowledge Glas Trösch AG, Schenker Storen AG, and RAICO Bautechnik GmbH Germany for providing materials for the test cell and the SEBF.

Conflicts of Interest: The authors declare no conflicts of interest. 


\section{References}

1. Laverge, J.; Schouwenaars, S.; Steeman, M.; Janssens, A.; van den Bossche, N. Condensation in a closed cavity double skin facade: A model for risk assessment. In Proceedings of the ICBEST, Vancouver, BC, Canada, 27-30 June 2010; Volume 2010, pp. 1-9.

2. Manz, H.; Frank, T. Thermal simulation of buildings with double-skin facades. Energy Build. 2005, 37, 1114-1121. [CrossRef]

3. Balocco, C. A simple model to study ventilated facades energy performance. Energy Build. 2002, 34, 469-475. [CrossRef]

4. Quesada, G.; Rousse, D.; Dutil, Y.; Badache, M.; Hallé, S. A comprehensive review of solar facades. Opaque solar facades. Rev. Renew. Sustain. Energy 2012, 16, 2820-2832. [CrossRef]

5. Hu, Z.; He, W.; Ji, J.; Zhang, S. A review on the application of Trombe wall system in buildings. Renew. Sustain. Energy Rev. 2017, 70, 976-987. [CrossRef]

6. Wang, D.; Hu, L.; Du, H.; Lui, Y.; Huang, J.; Xu, Y. Classification, experimental assessment, modeling methods and evaluation metrics of Trombe walls. Renew. Sustain. Energy Rev. 2020, 124. [CrossRef]

7. Ali, F.; Fariborz, H.; Hafia, E. Energy performance assessment of double-skin façade with thermal mass. Energy Build. 2010, 42, 1499-1509. [CrossRef]

8. Alvaro de, G.; Lidia, N.; Albert, C.; Álvaro, R.-P.; Servando, Á.; Luisa, F.C. Thermal analysis of a ventilated facade with PCM for cooling applications. Energy Build. 2013, 65, 508-515. [CrossRef]

9. Peng, J.; Curcija, D.C.; Lu, L.; Selkowitz, S.E.; Yang, H.; Zhang, W. Numerical investigation of the energy saving potential of a semi-transparent photovoltaic double-skin facade in a cool-summer Mediterranean climate. Appl. Energy 2016, 165, 345-356. [CrossRef]

10. Yongga, A.; Li, N.; Long, J.; He, Y. Thermal performance of a novel solar thermal facade system in a hot-summer and cold-winter zone. Sol. Energy 2020, 204, 106-114. [CrossRef]

11. Sánchez-Ostiz, A.; Monge-Barrio, A.; Domingo-Irigoyen, S.; González-Martínez, P. Design and experimental study of an industrialized sunspace with solar heat storage. Energy Build. 2014, 80, 231-246. [CrossRef]

12. Wüest, T.; Luible, A. Outdoor Test Cell Modelling with Modelica. Buildings 2019, 9, 209. [CrossRef]

13. Wüest, T.; Luible, A. Solar Energy Balanced Facade. Facade 2018-Adaptive! In Proceedings of the COST Action TU1403 Adaptive Facades Network Final Conference, Lucerne, Switzerland, 26-27 November 2018; pp. 183-194. [CrossRef]

14. De Boer, J. Lichttechnisches und energetisches Verhalten von Fassaden moderner Verwaltungsbauten, Teil 1: Lichttechnisches Verhalten. Bauphysik 2006, 28, 27-44. [CrossRef]

15. De Boer, J. Lichttechnisches und energetisches Verhalten von Fassaden moderner Verwaltungsbauten, Teil 2: Energetisches Verhalten. Bauphysik 2006, 28, 103-110. [CrossRef]

16. Favoino, F.; Jin, Q.; Overend, M. The route to an ideal adaptive glazing facade. In Proceedings of the ICBEST, Aachen, Germany, 9-12 June 2014.

17. ISO 15099. Thermal Performance of Windows, Doors and Shading Devices-Detailed Calculations; ISO: Geneva, Switzerland, 2003.

18. SN EN ISO 6946. Bauteile—Wärmedurchlasswiderstand und Wärmedurchgangskoeffizient_Berechnungsverfahren; SIA: Zürich, Switzerland, 2017.

19. EN ISO 10077-2. Thermal Performance of Windows, Doors and Shutters_Calculation of Thermal Transmittance-Part 2: Numerical Method for Frames; CEN_European Committee for Standardization: Bruxelles, Belgium, 2017.

20. Meteotest AG. Meteonorm V7.3.3; Meteotest AG: Bern, Switzerland, 2018.

21. European Committee for Standardization (CEN). EN 410 Glass in Building-Determination of Luminous and Solar Characteristics of Glazing; European Committee for Standardization (CEN): Bruxelles, Belgium, 2011.

22. Furler, R. Angular Dependence of Optical Properties of Homogeneous Glasses; Lawrence Berkeley National Laboratory: Berkeley, CA, USA, 1991; Available online: https://escholarship.org/uc/item/89j2v2tq (accessed on 16 March 2020).

23. Manz, H.; Menti, U.-P. Energy performance of glazings in European climates. Renew. Energy 2012, 37, 226-232. [CrossRef] 